\title{
Twisted Molecular Nanoribbons with up to 53 Linearly-Fused Rings
}

Rajeev K. Dubey, ${ }^{a}$ Manuel Melle-Franco ${ }^{b}$ and Aurelio Mateo-Alonso ${ }^{* a, c}$

a POLYMAT, University of the Basque Country UPV/EHU, Avenida de Tolosa 72, 20018 DonostiaSan Sebastian, Spain.

${ }^{\mathrm{b}}$ CICECO - Aveiro Institute of Materials, Department of Chemistry, University of Aveiro, 3810-193 Aveiro, Portugal.

${ }^{c}$ Ikerbasque, Basque Foundation for Science, Bilbao, Spain. 


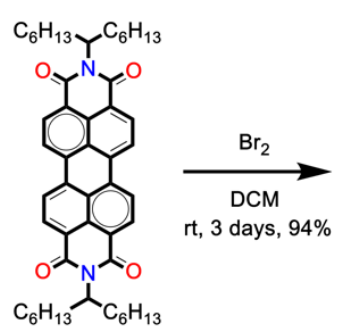

6

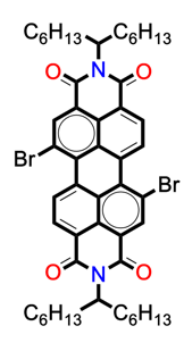

$1,7-\& 1,6-$

regioisomeric mixture<smiles>CC(C)(C)OP(C1=CC2CC(C(C)(C)C)CC3CCC4CC(C(C)(C)C)CC1C234)C(C)(C)C</smiles>

$\underset{\mathrm{Pd}(\mathrm{dppf}) \mathrm{Cl}_{2} \cdot \mathrm{DCM}}{\stackrel{8}{\longrightarrow}}$ TBACl

$1 \mathrm{M} \mathrm{K}_{2} \mathrm{CO}_{3}$ (aq.)

toluene, $85^{\circ} \mathrm{C}, \mathrm{N}_{2}$

$16 \mathrm{~h}, 89 \%$

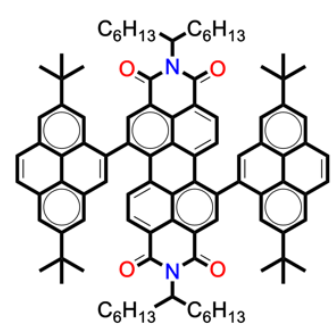

9

$1,7-\& 1,6-$

regioisomeric mixture
$\mathrm{DDQ}$
$\mathrm{BF}_{3} \cdot \mathrm{Et}_{2} \mathrm{O}$

anh. DCM, $\mathrm{N}_{2}$ $0^{\circ} \mathrm{C}-\mathrm{rt}, 2.5 \mathrm{~h}$ $96 \%$ 个

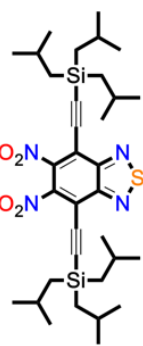

4<smiles></smiles>

5

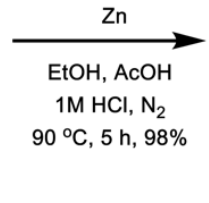

$1 \mathrm{M} \mathrm{HCl}, \mathrm{N}_{2}$

$90,5 \mathrm{~h}, 98 \%$

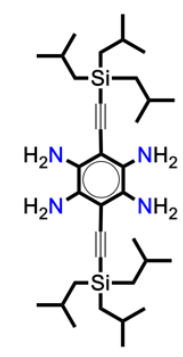

2
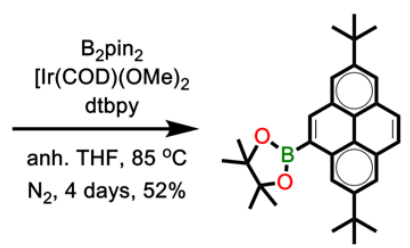

8

Scheme S1. Synthesis of compounds 1, 2 and 8. 

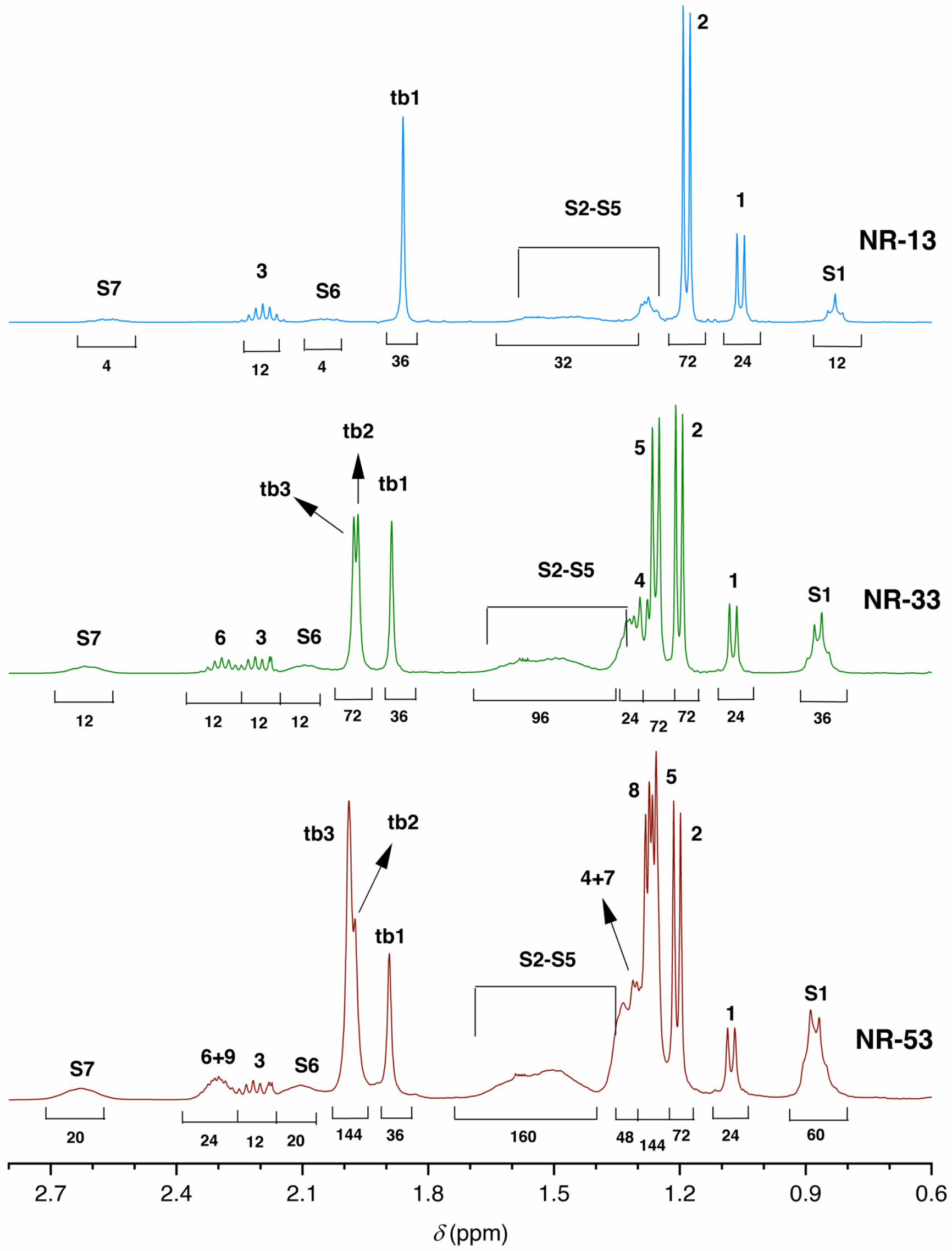

Figure S1. Aliphatic region of the $400 \mathrm{MHz}{ }^{1} \mathrm{H}$ NMR spectra of NR-13, NR-33, and NR-53 in $\mathrm{CDCl}_{3}$. Proton assignment shown on Figure 1. 

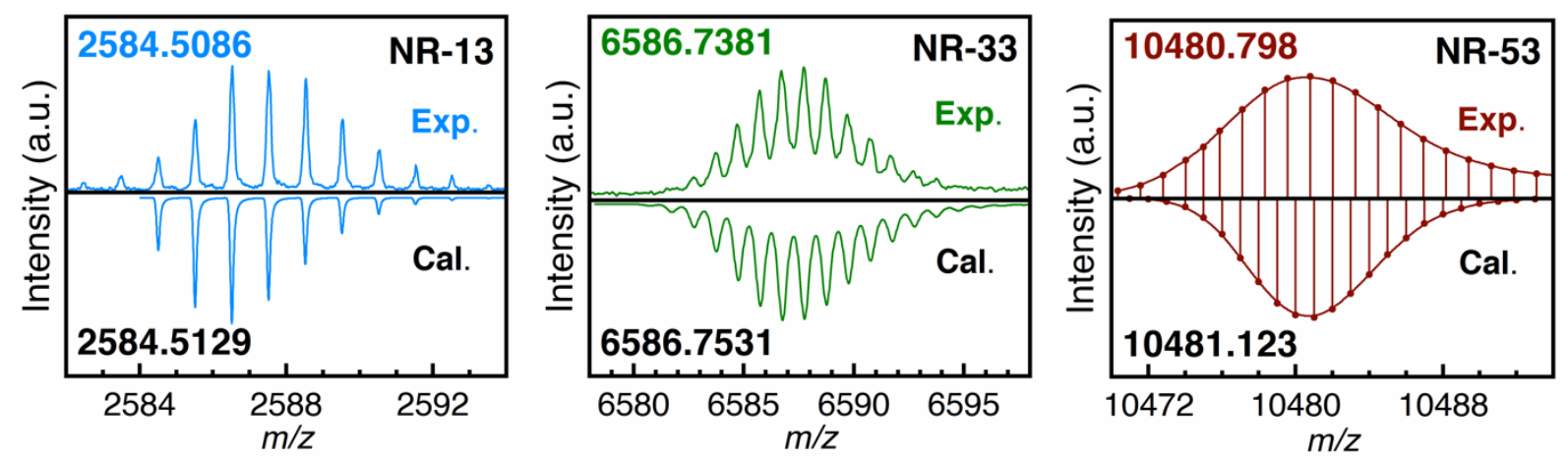

Figure S2. Experimental (top) and calculated (bottom) MALDI-TOF MS spectra of NR-13 $\left([\mathrm{M}+\mathrm{H}]^{+}\right), \mathbf{N R}-\mathbf{3 3}$ $\left([\mathrm{M}+\mathrm{Ag}]^{+}\right)$and NR-53 $\left([\mathrm{M}+\mathrm{Ag}]^{+}\right)$. 

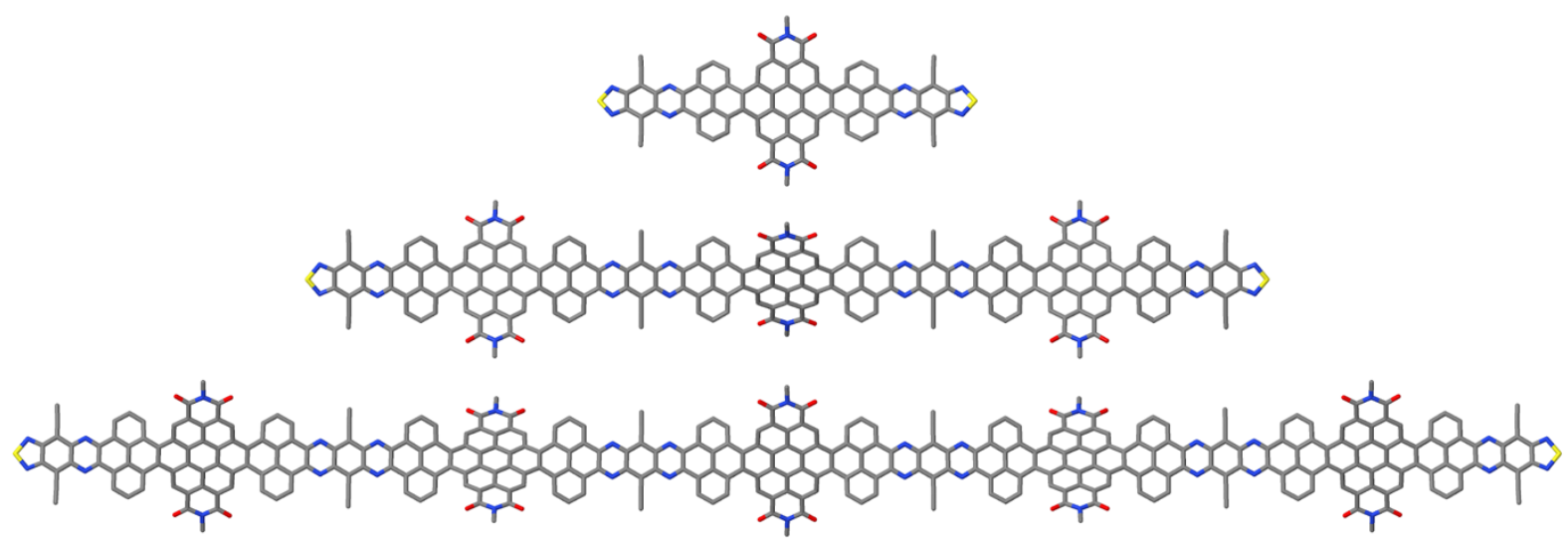

Figure S3. Models of NR-13-H, NR-33-H and NR-53-H, in which the solubilizing groups have been substituted by hydrogen atoms. 

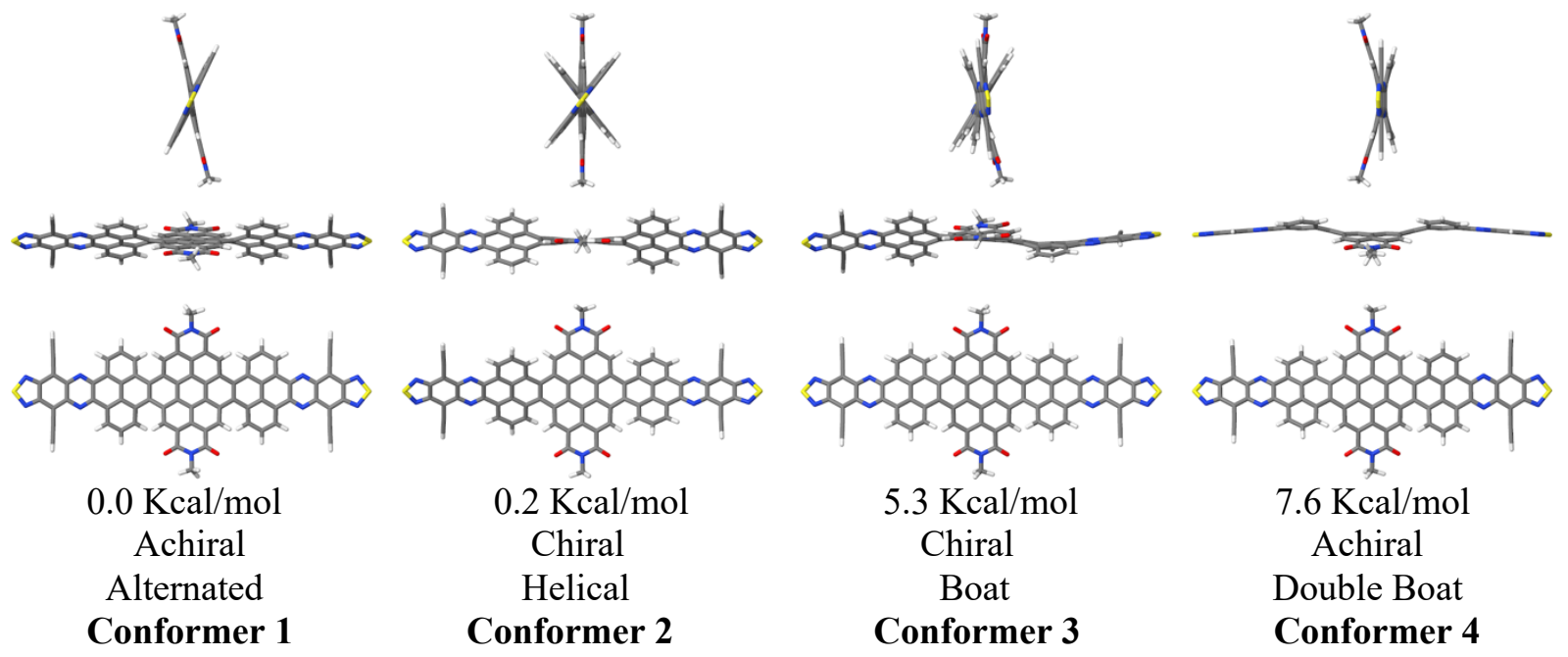

Figure S4. Four possible conformers of NR-13-H computed at the B3LYP-6-31G(d,p) level. 


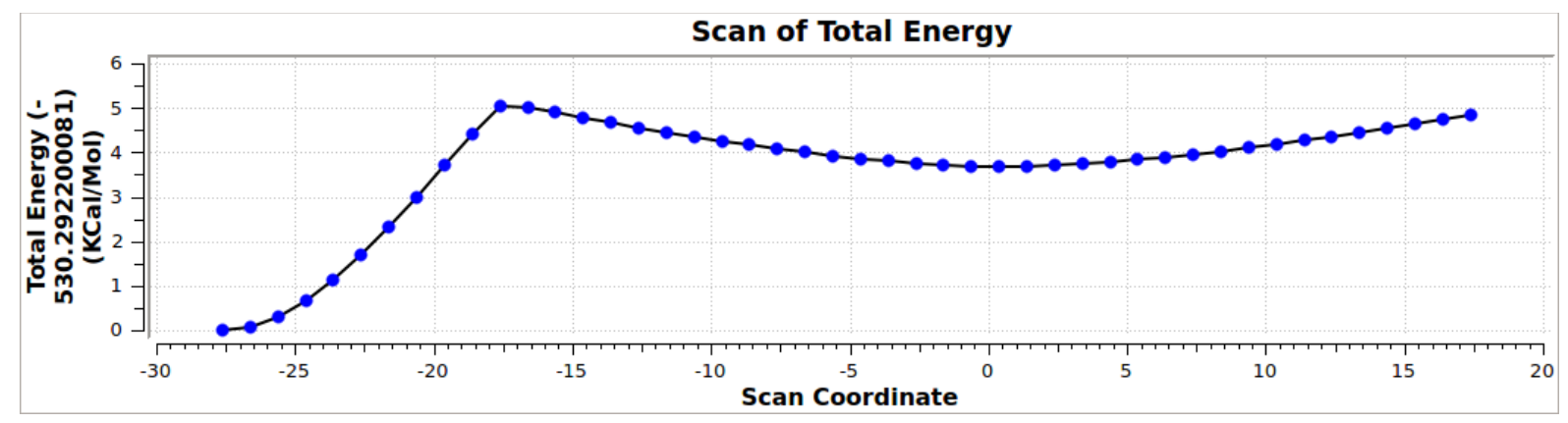

Figure S5. Activation energy to transform conformers 1 to 3 of NR-13-H shown on Figure S4 computed at the PM6 level. The energy of the direct transformation, conformer 1 to 3 , is $5 \mathrm{Kcal} / \mathrm{mol}$. The barrier for the inverse transformation, conformer 3 to 1 is $1.3 \mathrm{Kcal} / \mathrm{mol}$. All four conformations are accessible at RT, although only the first two are quantitatively populated. 

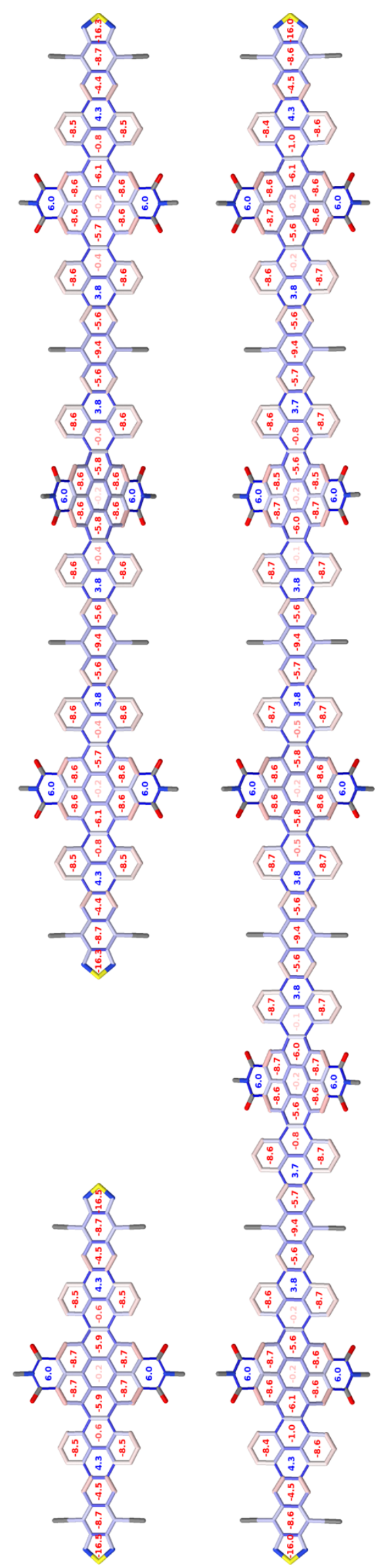

Figure S6. NICS $(0)$ at the B3LYP-6-31G(d,p) level. All values are ppm. Csp ${ }^{2}-\mathrm{Csp}^{2}$ and $\mathrm{Csp}^{2}-\mathrm{Nsp}^{2}$ bond alternation for the lowest energy structures at the B3LYP-6-31G(d,p) level, in vacuum colored by a scheme that highlights the bond alternation. Bonds are rendered in a color continuum ranging from red $(1.31 \mathrm{~A})$ to white $(1.40 \mathrm{~A})$ to blue $(1.49 \mathrm{~A})$ so that Clar's aromatic sextets are lighter/whiter colors and localized double and single bonds are red and blue respectively. 


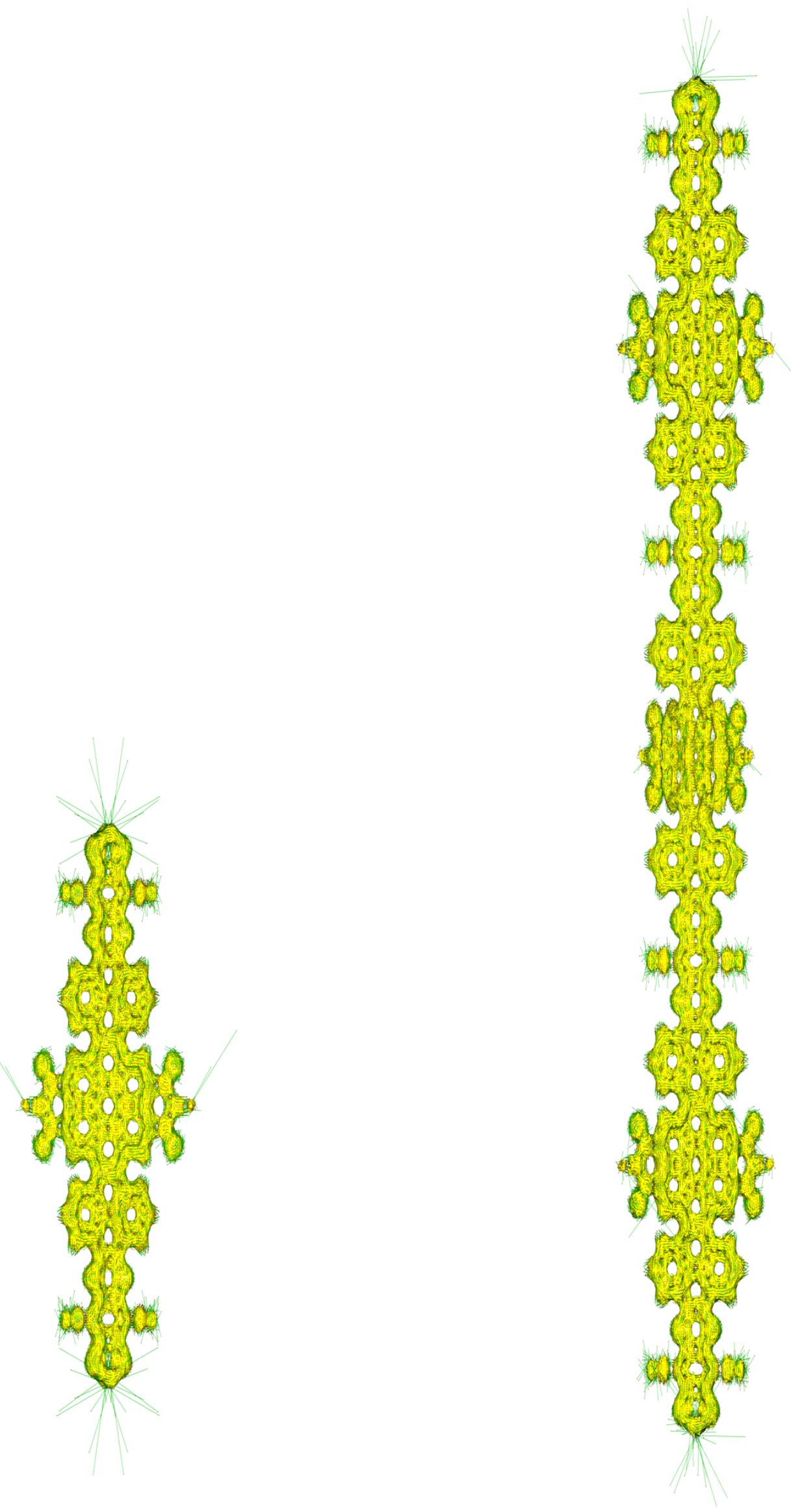

Figure S7. ACID plots of NR-13-H (left) and NR-33-H (right). 


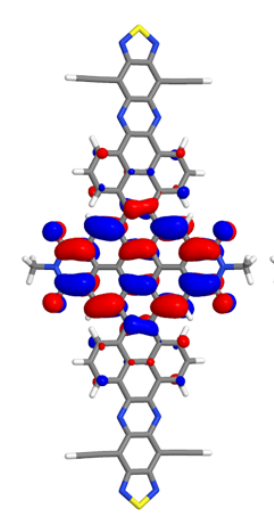

LUMO+2

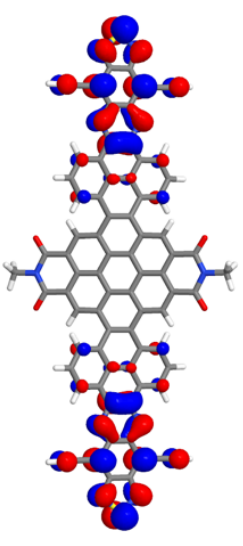

LUMO+1

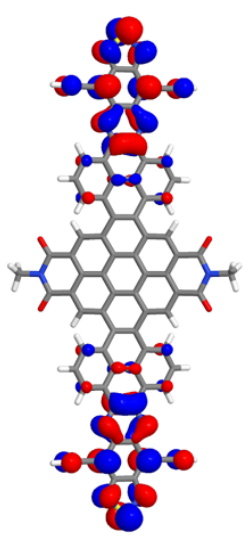

LUMO

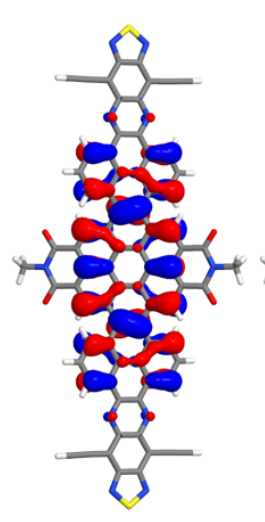

HOMO

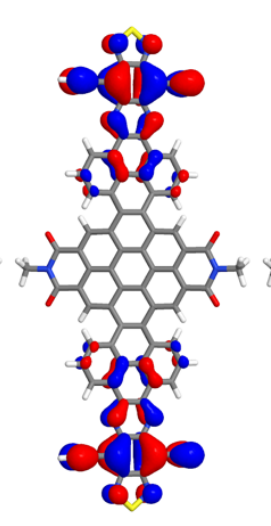

HOMO-1

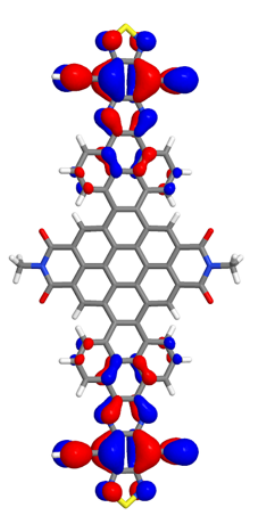

HOMO-2

Figure S8. B3LYP-6-31G(d,p)-Chloroform/B3LYP-6-31G(d,p) frontier orbitals for NR-13-H. Note the orbitals involved in the first TD-DFT electronic excitation in bold. 


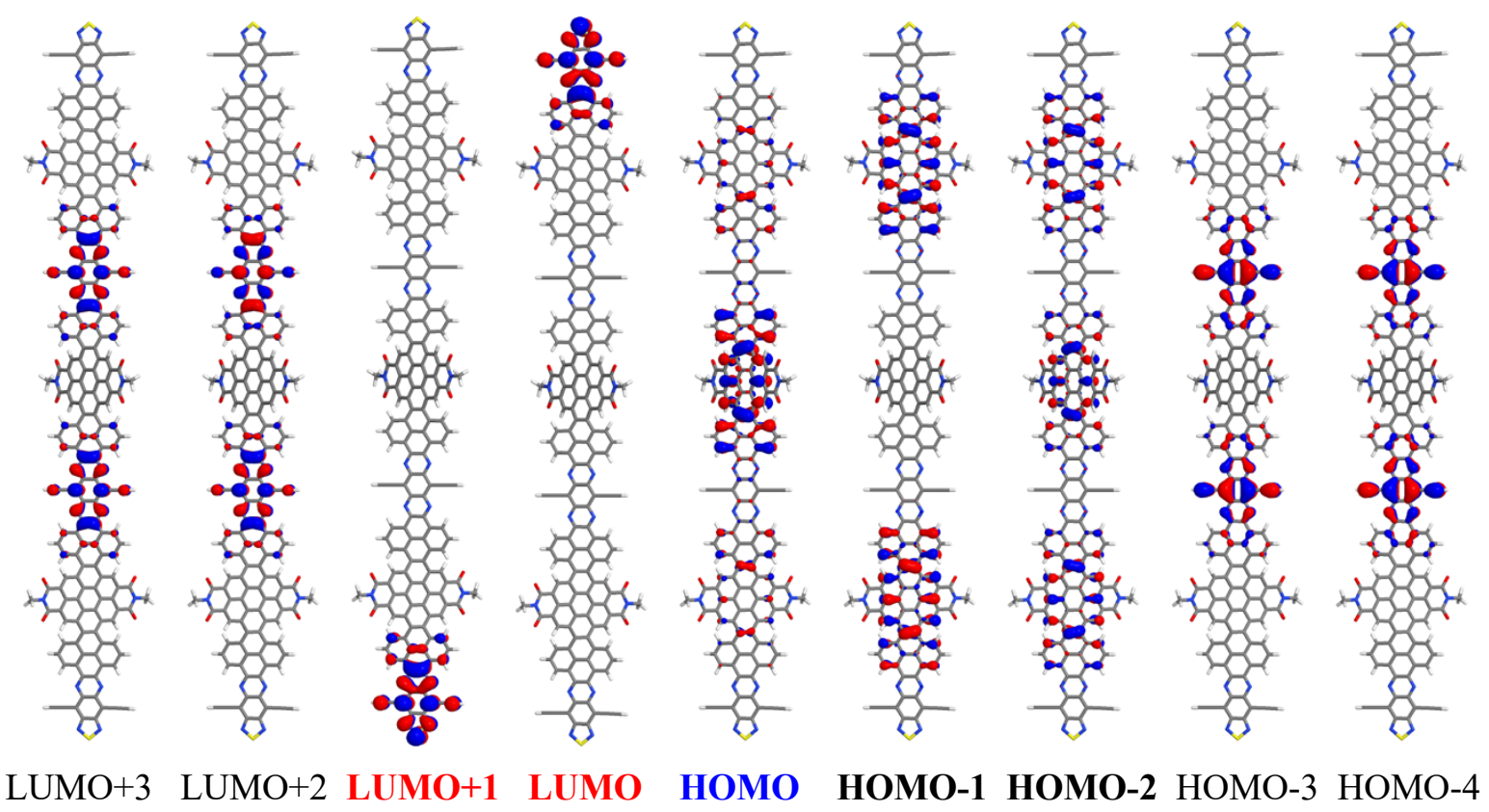

Figure S9. B3LYP-6-31G(d,p)-Chloroform/B3LYP frontier orbitals for NR-33-H. Note the orbitals involved in the first TD-DFT electronic excitation in bold. 


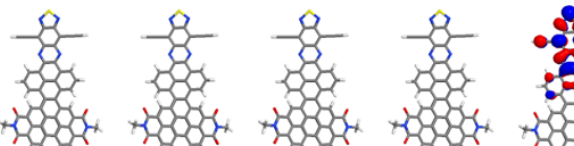
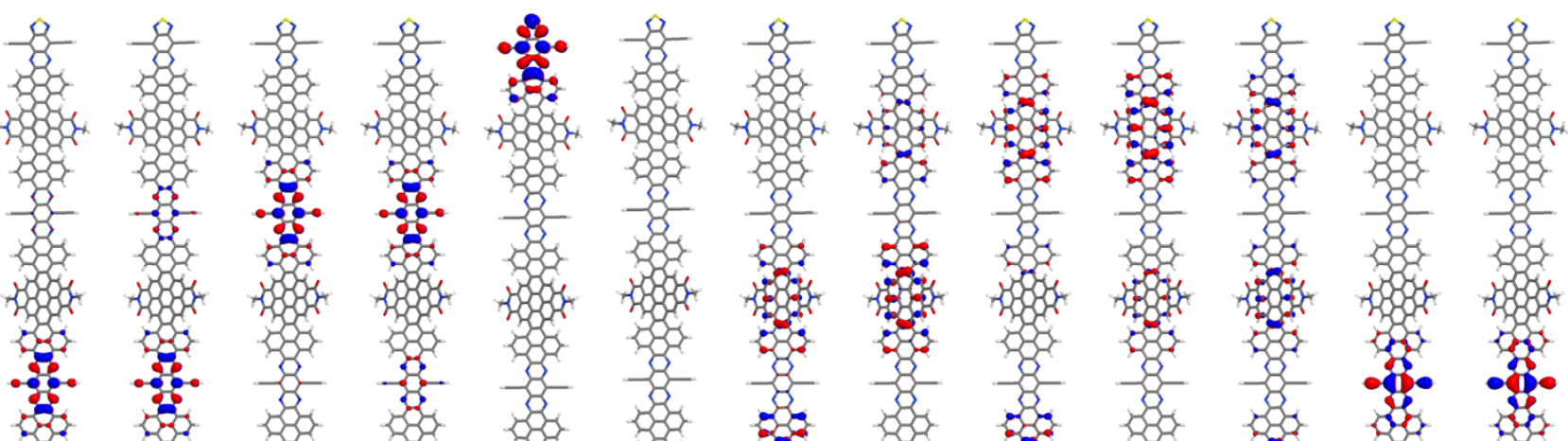

s

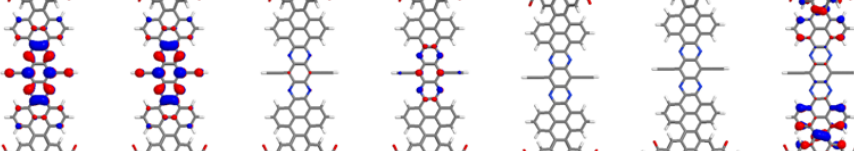

1.

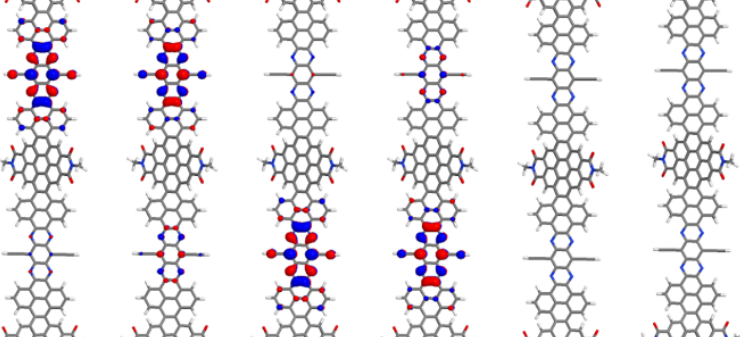

rom

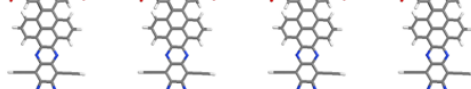

$\mathrm{LU}+5 \quad \mathrm{LU}+4 \quad \mathrm{LU}+3 \quad \mathrm{LU}+2$

(
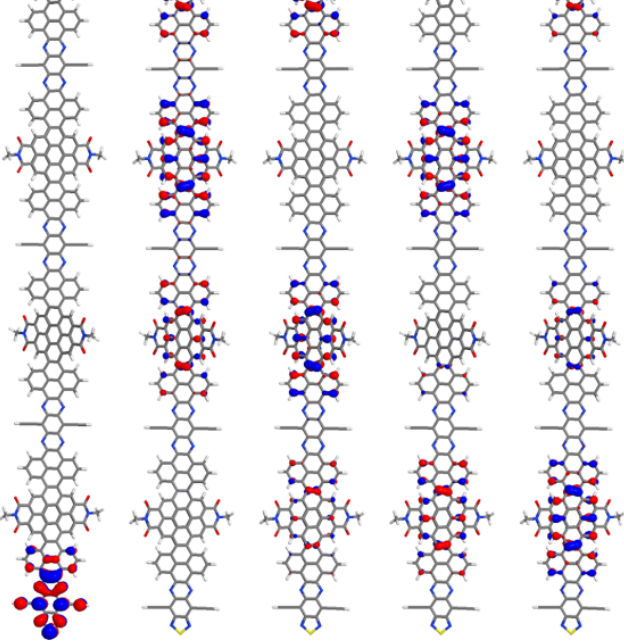

sist
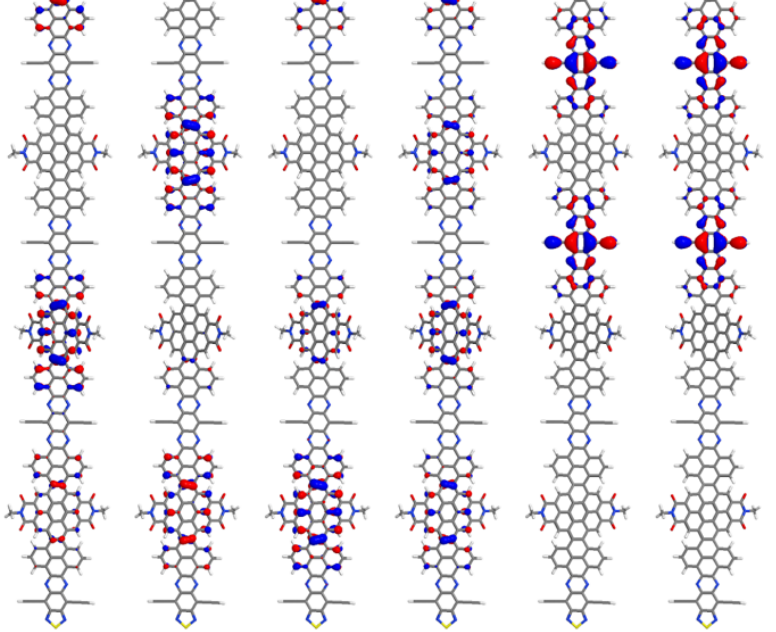

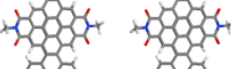

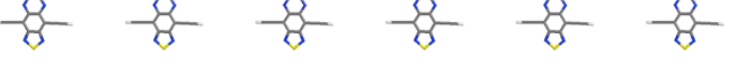

Figure S10. B3LYP-6-31G(d,p)-Chloroform/B3LYP frontier orbitals for NR-53-H. Note the orbitals involved in the first TD-DFT electronic excitation in bold. 
Table S1. Solubility of NRs in common organic solvents.

\begin{tabular}{|c|c|c|c|}
\hline Solvent & NR-13 & NR-33 & NR-53 \\
\hline $\mathbf{C H C l}_{\mathbf{3}}$ & $113 \mathrm{mg} / \mathrm{mL}$ & $54 \mathrm{mg} / \mathrm{mL}$ & $20 \mathrm{mg} / \mathrm{mL}$ \\
\hline $\mathbf{C H}_{\mathbf{2}} \mathbf{C l}_{\mathbf{2}}$ & $90 \mathrm{mg} / \mathrm{mL}$ & $21 \mathrm{mg} / \mathrm{mL}$ & $11 \mathrm{mg} / \mathrm{mL}$ \\
\hline THF & $112 \mathrm{mg} / \mathrm{mL}$ & $52 \mathrm{mg} / \mathrm{mL}$ & $17 \mathrm{mg} / \mathrm{mL}$ \\
\hline Toluene & $99 \mathrm{mg} / \mathrm{mL}$ & $43 \mathrm{mg} / \mathrm{mL}$ & $12 \mathrm{mg} / \mathrm{mL}$ \\
\hline
\end{tabular}


Table S2. Optical and Electronic Properties of NRs in Solution. ${ }^{a, b}$

\begin{tabular}{|c|c|c|c|c|c|c|c|c|c|}
\hline Compd & $\begin{array}{c}\lambda_{\text {abs }} \\
\left(\boldsymbol{\varepsilon}, \mathbf{M}^{-1} \mathbf{c m}^{-1}\right)\end{array}$ & $\begin{array}{c}\lambda_{\text {em }} \\
(\mathbf{n m})\end{array}$ & $\boldsymbol{\Phi}_{\mathbf{f}}{ }^{c}$ & $\mathbf{E}_{1 \text { red }}$ & $\mathbf{E}_{2 \text { red }}$ & $\mathbf{E}_{\text {3red }}$ & $\begin{array}{c}\mathbf{E}_{\mathbf{g}(\mathbf{o p t})} \\
(\mathbf{e V})^{\boldsymbol{d}}\end{array}$ & $\begin{array}{c}\mathbf{E}_{\text {LUMo }} \\
(\mathbf{e V})^{\boldsymbol{e}}\end{array}$ & $\begin{array}{c}\mathbf{E}_{\text {HOMo }} \\
(\mathbf{e V})^{f}\end{array}$ \\
\hline NR-13 & $\begin{array}{c}403(250100), \\
595(141000)\end{array}$ & 620 & 0.12 & -1.02 & -1.40 & -1.66 & 2.00 & -3.88 & -5.88 \\
\hline NR-33 & $\begin{array}{c}408(589500), \\
608(495000)\end{array}$ & 623 & 0.20 & -1.01 & -1.37 & -1.60 & 1.98 & -3.90 & -5.88 \\
\hline NR-53 & $\begin{array}{c}408(986100), \\
610(881000)\end{array}$ & 623 & 0.22 & -0.98 & -1.38 & -1.63 & 1.97 & -3.87 & -5.84 \\
\hline
\end{tabular}

${ }^{a}$ The absorption and emission were measured in $\mathrm{CHCl}_{3} .{ }^{b} \mathrm{The}$ redox potentials $\left(\mathrm{V} \mathrm{vs} \mathrm{Fc} / \mathrm{Fc}^{+}\right)$obtained by cyclic voltammetry in dichloromethane (Scan rate $=20 \mathrm{mV} / \mathrm{s}$ ). The potentials are reported as $E_{1 / 2}\left(=\left(E_{\mathrm{p}}{ }^{\mathrm{a}}+E_{\mathrm{p}}{ }^{\mathrm{c}}\right) / 2\right)$ and quoted to the nearest $0.01 \mathrm{~V}$. ${ }^{c}$ Fluorescence quantum yield. ${ }^{d}$ Optical band gap calculated using equation $E_{\mathrm{g}}=h c / \lambda_{\mathrm{ae}} \approx$ $1240 / \lambda_{\text {ae }}(\mathrm{nm})$; Where $\lambda_{\text {ae }}$ denotes the absorption edge wavelength in $\mathrm{nm}$, obtained from offset wavelength derived from the lowest energy absorption band. ${ }^{e}$ The LUMO levels were estimated from the onset of the first reduction potential $E_{\mathrm{LUMO}}=-\left(E_{1 \mathrm{red}(\mathrm{ONSET})}+4.8 \mathrm{eV}\right) .{ }^{f}$ Estimated from $E_{\text {Hомо }}=E_{\mathrm{LUMO}}-E_{\mathrm{g}}$. 
Table S3. TD-DFT computed with 12 excitations at the B3LYP-6-311+G(d,p)Chloroform $/ 6-31 G(\mathrm{~d}, \mathrm{p})$ level for NR-13H, NR-33H and NR53-H.

\begin{tabular}{|c|c|c|c|c|}
\hline Transition & $\begin{array}{l}\mathrm{E} \\
/ \mathrm{eV}\end{array}$ & $\begin{array}{l}\mathrm{E} \\
/ \mathrm{nm}\end{array}$ & $\begin{array}{l}\text { Osc. } \\
\text { Strenght }\end{array}$ & Contributions \\
\hline \multicolumn{5}{|l|}{ NR-13-H } \\
\hline 1 & 1.73 & 716 & 0.51 & HOMO->LUMO 97\%, H-4->L+1 2\% \\
\hline 2 & 1.75 & 709 & 0.00 & HOMO->L+1 98\% \\
\hline 3 & 1.94 & 640 & 0.00 & H-2->LUMO 48\%, H-1->L+1 51\% \\
\hline 4 & 1.94 & 640 & 0.23 & H-2->L+1 47\%, H-1->LUMO 52\% \\
\hline 5 & 2.10 & 591 & 0.66 & HOMO->L+2 94\% \\
\hline 6 & 2.11 & 587 & 0.00 & $\begin{array}{l}\text { H-3->LUMO 62\%, H-2->L+1 21\%, H-1->LUMO 13\% H-3- } \\
>\text { L+1 } 2 \%\end{array}$ \\
\hline \multicolumn{5}{|l|}{ NR-33-H } \\
\hline 1 & 1.72 & 722 & 0.77 & $\begin{array}{l}\text { H-2->LUMO 14\%, H-2->L+1 12\%, H-1->LUMO 24\%, H-1- } \\
>\text { - }+122 \%, \text { HOMO->LUMO 13\%, HOMO->L+1 11\% }\end{array}$ \\
\hline 2 & 1.72 & 722 & 0.00 & $\begin{array}{l}\text { H-2->LUMO 12\%, H-2->L+1 14\%, H-1->LUMO 22\%, H-1- } \\
>\text { L+1 24\%, HOMO->LUMO 11\%, HOMO->L+1 13\% }\end{array}$ \\
\hline 3 & 1.80 & 687 & 1.92 & H-1->L+3 15\%, HOMO->L+2 75\% H-10->L+3 3\% \\
\hline 4 & 1.83 & 677 & 0.00 & H-1->L+2 19\%, HOMO->L+3 76\% H-10->L+2 - $\%$ \\
\hline 5 & 1.88 & 660 & 0.02 & $\begin{array}{l}\text { H-2->LUMO 14\%, H-1->LUMO 10\%, HOMO->LUMO } \\
72 \% \text { HOMO->L }+13 \%\end{array}$ \\
\hline 6 & 1.88 & 660 & 0.01 & $\begin{array}{l}\text { H-2->L+1 14\%, H-1->L+1 } 10 \%, \quad \text { HOMO->L }+1 \quad 72 \% \\
\text { HOMO->LUMO } 3 \%\end{array}$ \\
\hline \multicolumn{5}{|l|}{ NR-53-H } \\
\hline 1 & 1.71 & 723 & 0.79 & $\begin{array}{l}\text { H-3->LUMO 16\%, H-3->L+1 13\%, H-2->LUMO 15\%, H-2- } \\
\text { >L+1 11\%, H-1->LUMO 10\% H-4->LUMO 9\%, H-4->L+1 } \\
\text { 7\%, H-1->L+1 8\%, HOMO->LUMO 3\%, HOMO->L+1 2\% }\end{array}$ \\
\hline 2 & 1.71 & 723 & 0.00 & $\begin{array}{l}\text { H-4->L+1 } 10 \%, \text { H-3->LUMO } 14 \%, \text { H-3->L+1 } 16 \%, \text { H-2- } \\
\text { >LUMO } 11 \%, \text { H-2->L+1 } 15 \%, \text { H-1->L+1 } 10 \% \\
\text { >LUMO 7\%, H-1->LUMO } 8 \%, \\
\text { HOMO->L+1 } 3 \%\end{array}$ \\
\hline 3 & 1.79 & 693 & 3.84 & $\begin{array}{l}\mathrm{H}-1->\mathrm{L}+314 \%, \mathrm{HOMO}->\mathrm{L}+220 \%, \mathrm{HOMO}->\mathrm{L}+436 \% \mathrm{H}- \\
3->\mathrm{L}+54 \%, \mathrm{H}-2->\mathrm{L}+48 \%, \mathrm{H}-1->\mathrm{L}+57 \%\end{array}$ \\
\hline 4 & 1.81 & 686 & 0.00 & $\begin{array}{l}\mathrm{H}-2->\mathrm{L}+3 \quad 11 \%, \quad \mathrm{H}-1->\mathrm{L}+2 \quad 34 \%, \quad \mathrm{HOMO}->\mathrm{L}+3 \quad 24 \%, \\
\text { HOMO->L+5 } 16 \% \text { H-3->L+4 } 3 \%, \mathrm{H}-2->\mathrm{L}+53 \%\end{array}$ \\
\hline 5 & 1.82 & 680 & 0.31 & $\begin{array}{l}\mathrm{H}-2->\mathrm{L}+2 \quad 20 \%, \mathrm{H}-1->\mathrm{L}+3 \quad 30 \%, \mathrm{HOMO}->\mathrm{L}+4-27 \% \mathrm{H}-1- \\
>\mathrm{L}+57 \%, \mathrm{HOMO}->\mathrm{L}+28 \%\end{array}$ \\
\hline 6 & 1.83 & 677 & 0.00 & $\begin{array}{l}\mathrm{H}-2->\mathrm{L}+3 \quad 11 \%, \mathrm{H}-1->\mathrm{L}+418 \%, \text { HOMO->L }+5 \quad-51 \% \mathrm{H}-1- \\
>\mathrm{L}+28 \%, \mathrm{HOMO}->\mathrm{L}+32 \%\end{array}$ \\
\hline
\end{tabular}




\title{
MATERIALS AND METHODS
}

Reagents. All the commercial reagents utilized in the synthesis were used as received. Following compounds were synthesized as reported previously: 4,7-bis-[(triisobutylsilyl)ethynyl]benzo[c] $[1,2,5]$ thiadiazole-5,6diamine $^{1}$ B, 5,6-dinitro-4,7-bis-[(triisobutylsilyl)ethynyl]benzo[c][1,2,5] thiadiazole $^{1} \mathbf{4}$, and $N, N^{\prime}$-Bis(1hexylheptyl)-perylene bisimide ${ }^{2} \mathbf{6}$.

Synthesis. All the reactions were performed in an oven-dried round-bottom flask, Schlenk tube or reaction vial. The required high temperature for the reactions was achieved by the use of an oil-bath or an aluminum heating block, unless otherwise noted. The reaction progress was regularly monitored by thin-layer chromatography on TLC plates for which visualization was realized either by visual observation with naked eye or by irradiation with UV lamp.

Purification. The purification of the products was performed by silica-gel column chromatography under ambient conditions. The sorbent for the column chromatography (silica gel 60, 0.04-0.06 mm, 230-400 mesh) and the TLC plates were purchased from commercial suppliers. The monitoring of the purification process was performed by thin-layer chromatography on TLC plates.

Characterization. The NMR spectra were recorded with 400 or $500 \mathrm{MHz}$ pulsed Fourier transform NMR spectrometer in deuterated solvents at room temperature. The chemical shift values are given in ppm and $J$ values in Hz. High-resolution mass spectra of all the compounds were recorded by Dr. Javier Calvo on UltrafleXtreme III MALDI tandem mass spectrometer (Bruker) in reflector acquisition operation mode and the samples were prepared in THF. Because of the high molecular weight, the mass spectrum of NR-53 was obtained in linear acquisition operation mode on Bruker Daltonics-Autoflex MALDI-TOF mass spectrometer by Dr. Estíbaliz González de San Román Martín.

Cyclic voltammetry. Electrochemical behavior of the compounds was studied using cyclic voltammetry in a three-electrode single-compartment cell consisting of a glassy carbon working electrode, silver wire as the reference electrode, and a platinum wire as the counter electrode with ferrocene $(\mathrm{Fc})$ as an internal reference $(0.5 \mathrm{mM})$. The cell was connected to the computer controlled potentiostat (Princeton Applied Research PARSTAT 2273). The measurements were carried out under $\mathrm{N}_{2}$ atmosphere in anhydrous $\mathrm{CH}_{2} \mathrm{Cl}_{2}$ using tetrabutylammonium hexafluorophosphate $(0.1 \mathrm{M})$ as the supporting electrolyte. The concentration of the prepared samples was ca. $0.5 \mathrm{mM}$. The potentials of all the reversible peaks are reported as $E_{1 / 2}=\left(E_{\mathrm{p}}{ }^{\mathrm{a}}+E_{\mathrm{p}}{ }^{\mathrm{c}}\right) / 2$ in $\mathrm{V} v \mathrm{Fc} / \mathrm{Fc}^{+}$and quoted to the nearest $0.01 \mathrm{~V}$.

\begin{abstract}
Absorption and emission spectroscopy. The absorption spectra were recorded with a double beam UV/VIS/NIR spectrophotometer (PerkinElmer - Lambda 950) and the emission spectra were collected on a fluorescence spectrometer (PerkinElmer - LS 55). Fluorescence quantum yields were determined by the comparative method using cresyl violet perchlorate ${ }^{3}\left(\Phi_{f}=0.54\right.$ in methanol $)$ as a standard.
\end{abstract}

Single crystal X-ray crystallography. The X-ray single crystal diffraction measurements were performed by Dr. Leire San Felices, from the X-ray diffraction unit of General Services SG-Iker (UPV/EHU). The intensity data were collected on an Agilent Technologies Super-Nova diffractometer, which was equipped with monochromated $\mathrm{Cu} \mathrm{k} \alpha$ radiation $(\lambda=1.54184 \AA)$ and Atlas CCD detector. Measurement was carried out at 150.00(10) K with the help of an Oxford Cryostream 700 PLUS temperature device. Data frames were processed (united cell determination, analytical absorption correction with face indexing, intensity data integration and correction for Lorentz and polarization effects) using the Crysalis software package. The structure was solved using Olex2 and refined by full-matrix least-squares with SHELXL-97. Final geometrical calculations were carried out with Mercury and PLATON as integrated in WinGX. Crystallographic data have been deposited with the Cambridge Crystallographic Data Centre as supplementary publication no. CCDC 2061916. These data can be obtained free of charge from The Cambridge Crystallographic Data Centre via www.ccdc.ac.uk/data.request/cif. 


\section{SYNTHETIC PROCEDURES}

\section{Synthesis of 1,2,4,5-tetraamino-3,6-bis-[(triisobutylsilyl)ethynyl]-benzene (2): ${ }^{4}$}

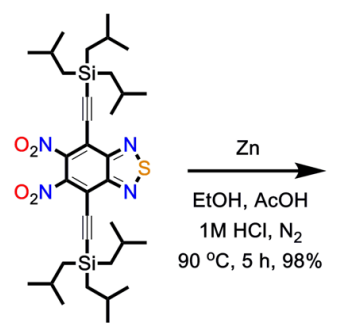

4

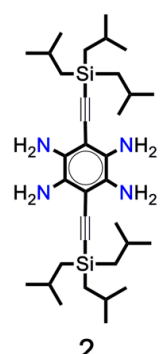

2

A mixture of 5,6-dinitro-4,7-bis-[(triisobutylsilyl)ethynyl]benzo[c][1,2,5]thiadiazole 4 (330 mg, $0.49 \mathrm{mmol}, 1$ eq.) and $\mathrm{Zn}$ powder (390 mg, $5.96 \mathrm{mmol}, 12$ eq.) was taken in an oven dried Schlenk tube. Subsequently, absolute ethanol $(24 \mathrm{~mL})$, acetic acid $(6 \mathrm{~mL})$, and $1 \mathrm{M} \mathrm{HCl}(3 \mathrm{~mL})$ were added and the content of the Schlenk tube was degassed by bubbling with $\mathrm{N}_{2}$. Afterwards, the Schlenk tube was sealed using a rubber septum and the resultant suspension was stirred for $5 \mathrm{~h}$ at $90{ }^{\circ} \mathrm{C}$ in an oil bath. After being cooled to room temperature, the reaction mixture was poured in water $(100 \mathrm{~mL})$ and the $\mathrm{pH}$ was adjusted to 6-7 by the addition of $1 \mathrm{M} \mathrm{NaOH}$. The solution was extracted with diethyl ether $(2 \times 100 \mathrm{~mL})$. The combined organic phase was dried with $\mathrm{Na}_{2} \mathrm{SO}_{4}$ and concentrated to obtain the crude product $2(280 \mathrm{mg}, 98 \%)$ as a brown dense oil. The crude product was used without further purification in the subsequent steps.

\section{Synthesis of $N, N^{\prime}$-Bis(1-hexylheptyl)-1,7(6)-dibromo-perylene-3,4,9,10-tetracarboxy bisimide (7):}

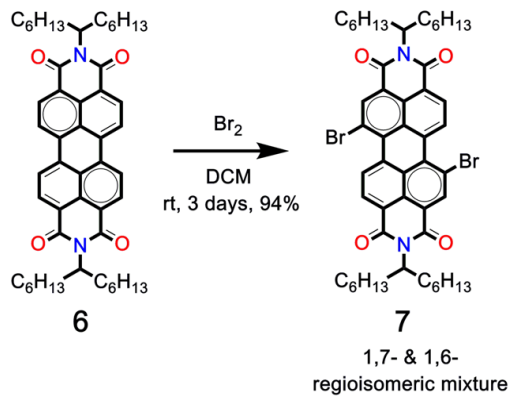

$N, N^{\prime}$-Bis(1-hexylheptyl)-perylene bisimide 6 (10.00 g, $13.24 \mathrm{mmol}, 1$ eq.) was dissolved in DCM (200 mL) in a $1 \mathrm{~L}$ round-bottom flask. Subsequently, a reflux condenser was placed on the flask and bromine $(60 \mathrm{~mL}$, $1,171.39 \mathrm{mmol}, 88$ eq.) was added. The condenser was sealed with a rubber septum and the reaction mixture was stirred for three days at room temperature. When the completion of the reaction was confirmed by TLC analysis, unreacted bromine was neutralized by the dropwise addition of a saturated aqueous solution of $\mathrm{Na}_{2} \mathrm{~S}_{2} \mathrm{O}_{3}$. The organic layer was extracted using a separatory funnel and later washed with several portions of water. The organic phase was collected and concentrated under reduced pressure to obtain the crude product, which was purified by silica-gel column chromatography $(2: 1$ hexane- DCM) to afford the product 7 (11.60 $\mathrm{g}, 94 \%)$ as a bright red amorphous solid. The product was a mixture of 1,7- and 1,6-regioisomers in a ratio ca. 3:1. ${ }^{5,6}{ }^{1} \mathrm{H} \mathrm{NMR}\left(400 \mathrm{MHz}, \mathrm{CDCl}_{3}\right): \delta=9.52(\mathrm{~d}, J=8 \mathrm{~Hz}, 2 \mathrm{H}), 8.95(\mathrm{br} \mathrm{d}, 2 \mathrm{H}), 8.73(\mathrm{br} \mathrm{s}, 2 \mathrm{H}), 5.25-5.15(\mathrm{~m}$, 2H), 2.33-2.21 (m, 4H), 1.92-1.82 (m, 4H), 1.45-1.20 (m, 32H), $0.86 \mathrm{ppm}(\mathrm{t}, J=8 \mathrm{~Hz}, 12 \mathrm{H}) .{ }^{13} \mathrm{C}\left\{{ }^{1} \mathrm{H}\right\} \mathrm{NMR}$ $\left(126 \mathrm{MHz}, \mathrm{CDCl}_{3}\right): \delta=164.17,163.69,163.04,162.50,138.48,137.82,133.13,132.88,132.75,132.35$, $130.50,130.40,129.76,129.29,128.46,128.09,128.05,128.00,127.20,126.39,123.78,123.37,123.05$, $122.66,121.58,120.76,55.21,55.01,54.82,32.40,32.33,32.26,31.76,31.62,29.23,29.20,29.18,26.92$, 26.88, 26.85, 26.73, 22.59, 22.45, 14.05 ppm. HRMS (MALDI-TOF): [M] Calculated for $\mathrm{C}_{50} \mathrm{H}_{60} \mathrm{Br}_{2} \mathrm{~N}_{2} \mathrm{O}_{4}$, 910.2917; found, 910.2961. Broadening (br) of peaks in the ${ }^{1} \mathrm{H}$ NMR spectrum is due to rotational isomers formed by the swallow tail at the imide-positions. 


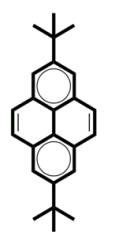

5

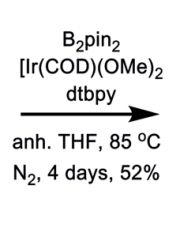

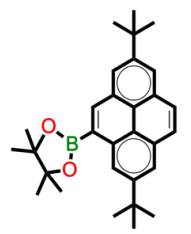

8

This compound was synthesized with an improvement to the previously reported procedure. ${ }^{7-8} 2,7$-di-tertbutylpyrene $\left(11.70 \mathrm{~g}, 37.20 \mathrm{mmol}, 1\right.$ eq.), $\mathrm{B}_{2} \mathrm{pin}_{2}(14.16 \mathrm{~g}, 55.76 \mathrm{mmol}, 1.5$ eq.), (1,5cyclooctadiene)(methoxy)iridium(I) dimer (1.23 g, $1.86 \mathrm{mmol}, 0.05$ eq.), and 4,4'-di-tert-butyl-2,2'bipyridine (dtbpy) (1.00 g, $3.73 \mathrm{mmol}, 0.10 \mathrm{eq}$.) were placed in an oven dried Schlenk tube. Anhydrous THF ( $45 \mathrm{~mL}$ ) was added and the content of the Schlenk tube was degassed by bubbling with $\mathrm{N}_{2}$. Afterwards, the Schlenk tube was sealed using a rubber septum and the reaction mixture was stirred for 4 days at $85^{\circ} \mathrm{C}$ in an oil bath. After being cooled to room temperature, the reaction mixture was poured in water $(200 \mathrm{~mL})$ and the crude product was extracted with DCM $(3 \times 200 \mathrm{~mL})$. The combined organic phase was concentrated and the residue was purified by silica-gel column chromatography eluting with $4: 1$ hexane- DCM to afford the product $8(8.52 \mathrm{~g}, 52 \%)$ as a white solid. From the column, unreacted 2,7-di-tert-butylpyrene $(2.80 \mathrm{~g}, 24 \%)$ and the side product 4,9(10)-bis(Bpin)-2,7-di-tert-butylpyrene $(4.21 \mathrm{~g}, 20 \%)$ were also collected. ${ }^{1} \mathrm{H}$ NMR $\left(400 \mathrm{MHz}, \mathrm{CDCl}_{3}\right): \delta=9.21(\mathrm{~d}, J=2 \mathrm{~Hz}, 1 \mathrm{H}), 8.70(\mathrm{~s}, 1 \mathrm{H}), 8.27(\mathrm{~d}, J=2 \mathrm{~Hz}, 1 \mathrm{H}), 8.22(\mathrm{~d}, J=2 \mathrm{~Hz}, 1 \mathrm{H})$, $8.19(\mathrm{~d}, J=2 \mathrm{~Hz}, 1 \mathrm{H}), 8.03(\mathrm{AB}$ quartet, $J=8 \mathrm{~Hz}, 2 \mathrm{H}), 1.62(\mathrm{~s}, 9 \mathrm{H}), 1.59(\mathrm{~s}, 9 \mathrm{H}), 1.54 \mathrm{ppm}(\mathrm{s}, 12 \mathrm{H}) .{ }^{13} \mathrm{C}\left\{{ }^{1} \mathrm{H}\right\}$ NMR (101 MHz, $\left.\mathrm{CDCl}_{3}\right): \delta=148.38,148.28,138.50,133.05,130.70,130.64,129.90,127.88,126.66$, $124.01,123.41,122.87,122.78,122.72,121.82,83.75,35.37,31.92,25.09$ ppm. HRMS (MALDI-TOF): $[\mathrm{M}]^{+}$Calculated for $\mathrm{C}_{30} \mathrm{H}_{37} \mathrm{BO}_{2}, 440.2889$; found, 440.2927 .

\section{Synthesis of Compound 9:}
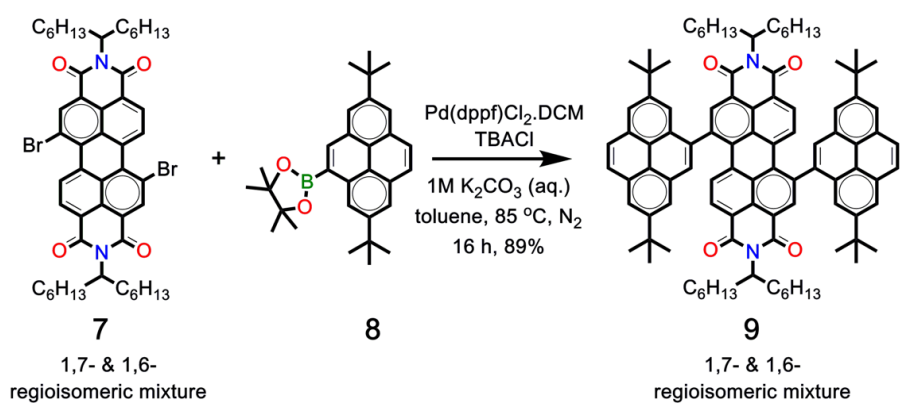

A $1 \mathrm{~L}$ round-bottomed flask was charged with dibromo-PBI 7 (4.00 g, $4.38 \mathrm{mmol}, 1$ eq.), pyrene derivative 8 (4.06 g, $9.22 \mathrm{mmol}, 2.1$ eq.), tetrabutylammonium chloride $(0.24 \mathrm{~g}, 0.86 \mathrm{mmol}, 0.2 \mathrm{eq}$.$) , and$ $\mathrm{Pd}$ (dppf)Cl 2 .DCM ( $0.72 \mathrm{~g}, 0.88 \mathrm{mmol}, 0.2$ eq.). Subsequently, toluene $(400 \mathrm{~mL})$ and $1 \mathrm{M}$ aqueous solution of $\mathrm{K}_{2} \mathrm{CO}_{3}(200 \mathrm{~mL})$ was added. The reaction mixture was deaerated using vacuum and backfilled with nitrogen three times. Thereafter, the flask was sealed using a rubber septum and a $\mathrm{N}_{2}$ balloon was placed. The reaction temperature was raised to $85{ }^{\circ} \mathrm{C}$ and the reaction was stirred for $16 \mathrm{~h}$ under an inert atmosphere. After being cooled to room temperature, the organic phase was separated using a separatory funnel and washed with water $(2 \times 300 \mathrm{~mL})$. The organic phase was collected, and toluene was evaporated under reduced pressure. The solid residue was chromatographed on silica, eluting with 4:1 hexane-DCM, to afford the desired product $(5.37 \mathrm{~g}, 89 \%)$ as blackish-red crystalline solid. Herein, it is emphasized that the product was a mixture of 1,7and 1,6-regioisomers ${ }^{5,6}$ and used in the next step as it is. ${ }^{1} \mathrm{H}$ NMR $\left(400 \mathrm{MHz}, \mathrm{CDCl}_{3}\right): \delta=9.18-8.86(\mathrm{~m}, 2 \mathrm{H})$, $8.68(\mathrm{~s}, 0.5 \mathrm{H}), 8.46(\mathrm{~d}, J=12 \mathrm{~Hz}, 1.5 \mathrm{H}), 8.42-8.31(\mathrm{~m}, 3 \mathrm{H}), 8.31-8.23(\mathrm{~m}, 2 \mathrm{H}), 8.22-8.02(\mathrm{~m}, 8 \mathrm{H}), 8.01-7.90$ $(\mathrm{m}, 1 \mathrm{H}), 7.82-7.48(\mathrm{~m}, 2 \mathrm{H}), 5.38-4.88(\mathrm{~m}, 2 \mathrm{H}), 2.46-1.96(\mathrm{~m}, 4 \mathrm{H}), 1.74-1.53(\mathrm{~m}, 24 \mathrm{H}), 1.34-1.12(\mathrm{~m}, 39 \mathrm{H})$, $1.04(\mathrm{~s}, 9 \mathrm{H}), 0.94-0.82 \mathrm{ppm}(\mathrm{m}, 12 \mathrm{H}) .{ }^{13} \mathrm{C}\left\{{ }^{1} \mathrm{H}\right\} \mathrm{NMR}\left(126 \mathrm{MHz}, \mathrm{CDCl}_{3}\right): \delta=165.18,165.02,164.86$, $164.74,164.57,163.88,163.78,163.68,163.60,163.38,149.53,149.52,149.48,149.09,148.59,148.39$, $140.05,140.00,139.86,139.74,139.44,139.26,138.03,137.34,136.71,135.24,135.15,134.57,134.31$, $134.13,133.48,131.70,131.67,131.63,131.47,131.26,131.20,131.12,131.07,130.82,130.58,129.99$, $129.78,129.64,129.60,129.29,129.08,128.89,128.60,128.48,128.39,128.35,128.29,128.25,128.16$, $128.04,127.91,127.76,127.64,127.54,126.18,125.93,123.89,123.81,123.74,123.60,123.47,123.41$, $123.31,123.16,123.14,123.11,123.08,123.05,122.99,122.82,122.10,122.00,120.42,120.18,119.89$, $55.16,54.85,54.53,35.60,35.56,35.38,35.12,34.82,32.78,32.73,32.52,32.31,32.25,32.22,32.18,32.08$, $32.06,32.03,32.01,31.97,31.91,31.77,31.74,31.69,31.22,29.58,29.54,29.50,29.47,29.40,29.37,29.34$, 


\section{Synthesis of Compound 1:}
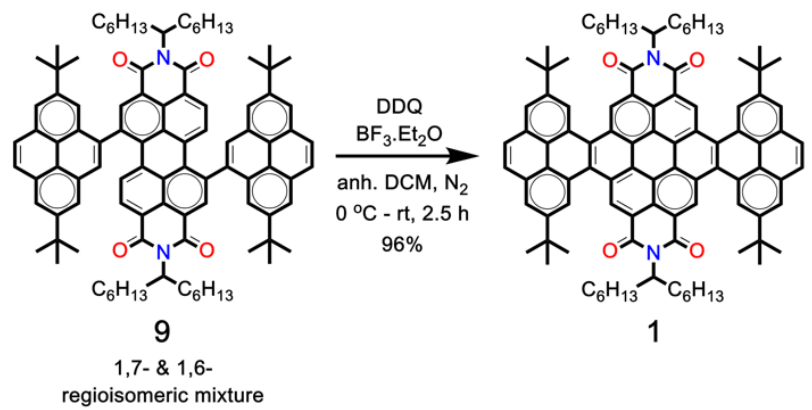

Compound 9 (2.50 g, $1.81 \mathrm{mmol}, 1$ eq.) was dissolved in anhydrous DCM (500 mL) in an oven dried 1L round-bottom flask. Subsequently, boron trifluoride diethyl etherate $\left(\mathrm{BF}_{3} . \mathrm{Et}_{2} \mathrm{O}\right)(3.0 \mathrm{~mL}, 3.45 \mathrm{~g}, 24.30 \mathrm{mmol}$, 13 eq.) was added and the reaction mixture was deaerated by employing three cycles of vacuum-nitrogen. Thereafter, the flask was sealed using a rubber septum. The solution was cooled to $0{ }^{\circ} \mathrm{C}$ in an ice bath for about 20 minutes and DDQ (2.50 g, $11.01 \mathrm{mmol}, 6 \mathrm{eq}$.) was added. The reaction mixture was stirred at room temperature for $2 \mathrm{~h}$ under an inert atmosphere. During this course of time, the color of the reaction mixture turned red to dark green. After ensuring the completion of the reaction by TLC analysis, reaction was quenched by the addition of a saturated aqueous solution of $\mathrm{NaHCO}_{3}(100 \mathrm{~mL})$. The DCM solution was extracted using a separatory funnel and washed with water $(2 \times 300 \mathrm{~mL})$. Finally, the organic phase was collected and concentrated using rotary evaporation. The solid residue was washed with methanol and acetone to obtain the pure product $\mathbf{1}(2.39 \mathrm{~g}, 96 \%)$ as dark-green amorphous solid. Note: the compound has red-purple fluorescence in solution. ${ }^{1} \mathrm{H}$ NMR $\left(400 \mathrm{MHz}, \mathrm{CDCl}_{3}\right): \delta=11.16$ (br s, 2H), 11.11 (br s, 2H), $9.54(\mathrm{~s}, 4 \mathrm{H})$, $8.51(\mathrm{~s}, 4 \mathrm{H}), 8.31(\mathrm{~s}, 4 \mathrm{H}), 5.62-5.53(\mathrm{~m}, 2 \mathrm{H}), 2.64-2.53(\mathrm{~m}, 4 \mathrm{H}), 2.10-2.00(\mathrm{~m}, 4 \mathrm{H}), 1.80(\mathrm{~s}, 36 \mathrm{H}), 1.55-1.24$ $(\mathrm{m}, 32 \mathrm{H}), 0.85 \mathrm{ppm}(\mathrm{t}, J=8.0 \mathrm{~Hz}, 12 \mathrm{H}) .{ }^{13} \mathrm{C}\left\{{ }^{1} \mathrm{H}\right\} \mathrm{NMR}\left(126 \mathrm{MHz}, \mathrm{CDCl}_{3}\right): \delta=166.32,165.14,149.40$, $131.55,131.23,130.81,129.20,127.79,127.26,126.58,124.03,123.72,123.68,123.52,122.36,121.86$, $121.21,54.85,35.61,32.59,31.89,31.83,29.34,26.97,22.63,14.06$ ppm. HRMS (MALDI-TOF): [M] ${ }^{+}$ Calculated for $\mathrm{C}_{98} \mathrm{H}_{106} \mathrm{~N}_{2} \mathrm{O}_{4}, 1374.8149$; found, 1374.8156 .

\section{Synthesis of building-block A:}

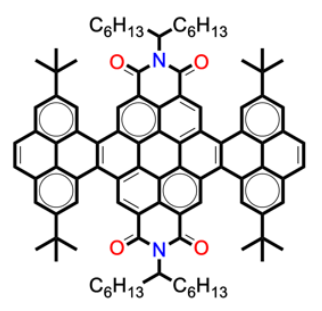

1

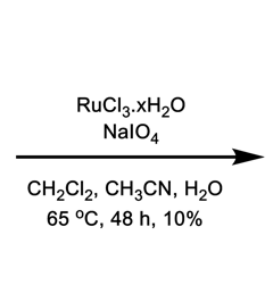
${ }^{\circ} \mathrm{C}, 48 \mathrm{~h}, 10 \%$

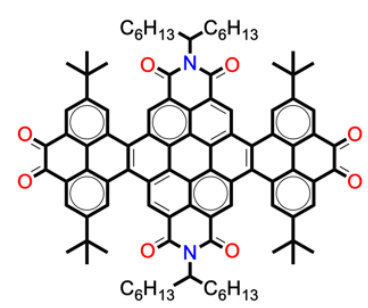

Building-block $\mathrm{A}$

A mixture of compound 1 (2.50 g, $1.82 \mathrm{mmol}, 1$ eq.), $\mathrm{RuCl}_{3} \cdot \mathrm{xH}_{2} \mathrm{O}$ (0.06 g, 0.29 mmol, 0.16 eq.), and $\mathrm{NaIO}_{4}$ $(1.87 \mathrm{~g}, 8.74 \mathrm{mmol}, 4.8$ eq.) was taken in a $1 \mathrm{~L}$ round-bottomed flask. Subsequently, DCM (200 mL), acetonitrile $(200 \mathrm{~mL})$, and water $(200 \mathrm{~mL})$ were added. The resultant mixture was stirred at $65{ }^{\circ} \mathrm{C}$ for $48 \mathrm{~h}$ and then allowed to cool to room temperature. The organic phase was collected using a separatory funnel and washed with water $(2 \times 300 \mathrm{~mL})$. The solvents were removed by evaporation under reduced pressure. The solid residue was purified by column chromatography (silicalDCM) to achieve the product $(0.26 \mathrm{~g}, 10 \%)$ as a red solid. Important to notice that the conversion yield of building-block $\mathbf{A}$ is $20 \%$ as unreacted compound $\mathbf{1}$ $(1.25 \mathrm{~g}, 50 \%)$ was recovered from the column. ${ }^{1} \mathrm{H}$ NMR (400 MHz, $\left.\mathrm{CDCl}_{3}\right): \delta=10.88(\mathrm{br} \mathrm{s}, 2 \mathrm{H}), 10.84$ (br s, 2H), $9.46(\mathrm{~s}, 4 \mathrm{H}), 8.88(\mathrm{~s}, 4 \mathrm{H}), 5.60-5.51(\mathrm{~m}, 2 \mathrm{H}), 2.60-2.49(\mathrm{~m}, 4 \mathrm{H}), 2.10-2.00(\mathrm{~m}, 4 \mathrm{H}), 1.69(\mathrm{~s}, 36 \mathrm{H})$, $1.53-1.22(\mathrm{~m}, 32 \mathrm{H}), 0.84 \mathrm{ppm}(\mathrm{t}, J=8.0 \mathrm{~Hz}, 12 \mathrm{H}) .{ }^{13} \mathrm{C}\left\{{ }^{1} \mathrm{H}\right\}$ NMR $\left(126 \mathrm{MHz}, \mathrm{CDCl}_{3}\right): \delta=180.57,165.75$, $164.54,152.14,134.75,131.44,130.72$, 129.95, 129.03, 128.87, 127.92, 127.77, 126.60, 124.20, 123.63, $122.37,122.09,121.70,55.18,35.69,32.48,31.79,31.18,29.26,26.95,22.59,14.04$ ppm. HRMS (MALDITOF): $[\mathrm{M}+\mathrm{H}]^{+}$Calculated for $\mathrm{C}_{98} \mathrm{H}_{103} \mathrm{~N}_{2} \mathrm{O}_{8}, 1435.7711$; found, 1435.7748 . 

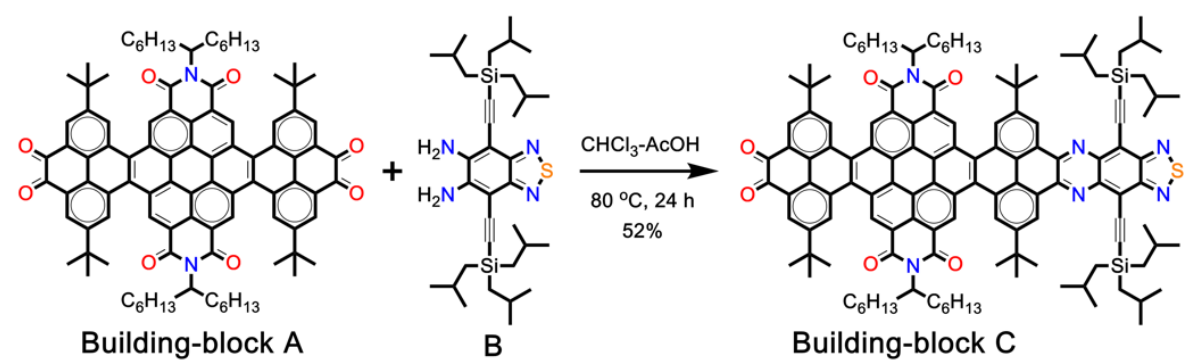

The tetraketone-based building-block A $(300 \quad \mathrm{mg}, \quad 0.21 \quad \mathrm{mmol}, \quad 1 \quad$ eq. $)$ and 4,7bis((triisobutylsilyl)ethynyl)benzo[c][1,2,5]thiadiazole B (153 mg, $0.25 \mathrm{mmol}, 1.2$ eq.) were taken in an ovendried Schlenk tube. Subsequently, acetic acid $(10 \mathrm{~mL})$ and anhydrous chloroform $(30 \mathrm{~mL})$ were added. The Schlenk tube was closed with a septum and the reaction mixture was stirred at $80{ }^{\circ} \mathrm{C}$ for $24 \mathrm{~h}$. After being cooled to room temperature, the reaction mixture was poured in chloroform $(100 \mathrm{~mL})$ and the resultant organic layer was washed with water $(2 \times 200 \mathrm{~mL})$. The organic layer was collected and concentrated under reduced pressure to obtain the crude product, which was purified by silica-gel column chromatography. The column was first eluted with a 2:1 mixture of hexane-DCM to collect the side-product NR-13 (168 mg, 31\%) as a dark-red solid. Subsequently, with a 1:1 mixture of hexane- DCM to collect the desired product (219 mg, $52 \%)$ as a dark-red solid. At the end, the unreacted building-block $\mathbf{A}$ was collected by eluting the column with DCM (45 mg, 15\%). ${ }^{1} \mathrm{H}$ NMR (400 MHz, $\mathrm{CDCl}_{3}$ ): $\delta=11.11$ (br. S, $\left.1 \mathrm{H}\right), 11.06$ (br. S, $\left.1 \mathrm{H}\right), 10.88$ (br. S, 1H), 10.84 (br. S, 1H), 10.09 (s, 2H), 9.60 (s, 2H), 9.50 (s, 2H), 8.88 (s, 2H), 5.61-5.53 (m, 2H), 2.62-2.50 $(\mathrm{m}, 4 \mathrm{H}), 2.27-2.17(\mathrm{~m}, 6 \mathrm{H}), 2.13-2.02(\mathrm{~m}, 4 \mathrm{H}), 1.88(\mathrm{~s}, 18 \mathrm{H}), 1.70(\mathrm{~s}, 18 \mathrm{H}), 1.52-1.27(\mathrm{~m}, 32 \mathrm{H}), 1.21(\mathrm{~d}, J=$ $8.0 \mathrm{~Hz}, 36 \mathrm{H}), 1.08(\mathrm{~d}, J=8.0 \mathrm{~Hz}, 12 \mathrm{H}), 0.85 \mathrm{ppm}(\mathrm{t}, J=8.0 \mathrm{~Hz}, 12 \mathrm{H}) .{ }^{13} \mathrm{C}\left\{{ }^{1} \mathrm{H}\right\} \mathrm{NMR}\left(126 \mathrm{MHz}, \mathrm{CDCl}_{3}\right): \delta=$ $180.98,166.21,165.01,155.33,152.34,151.21,146.10,142.14,135.04,132.25,131.32,130.58,130.23$, $129.59,129.43,129.08,128.93,128.56,128.15,128.03,127.29,126.79,126.24,124.80,124.64,124.27$, $123.90,122.48,121.78,114.58,113.28,101.89,55.38,36.19,35.96,32.80,32.13,32.07,31.47,29.94,29.55$, 27.23, 26.86, 25.51, 25.47, 22.86, $14.32 \mathrm{ppm}$. HRMS (MALDI-TOF): $[\mathrm{M}+\mathrm{H}]^{+}$Calculated for $\mathrm{C}_{132} \mathrm{H}_{157} \mathrm{~N}_{6} \mathrm{O}_{6} \mathrm{SSi}_{2}, 2010.1420$; found, 2010.1545.

\section{Synthesis of Compound 3:}
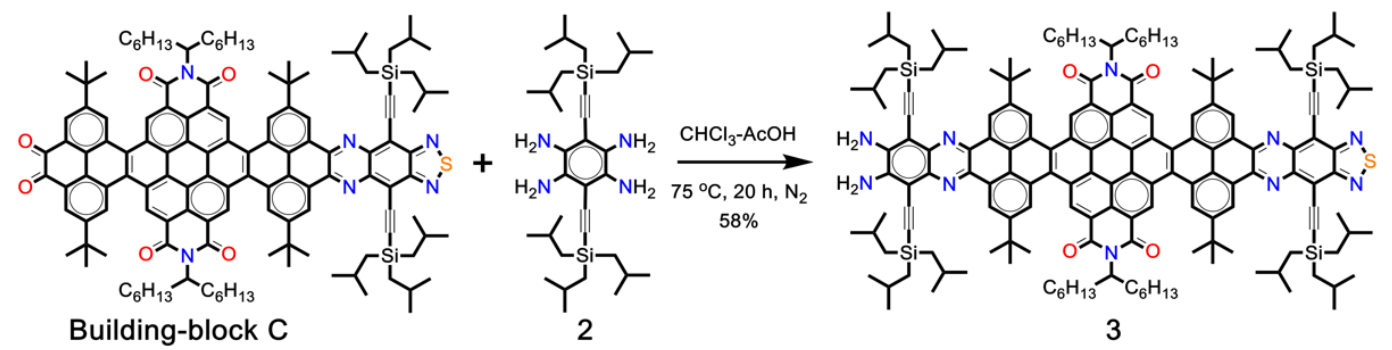

An oven dried Schlenk tube was charged with building-block C (100 mg, $0.05 \mathrm{mmol}, 1$ eq.) and tetraaminobenzene 2 (150 mg, $0.26 \mathrm{mmol}, 5$ eq.). Subsequently, acetic acid (1.5 mL) and anhydrous chloroform (3 $\mathrm{mL}$ ) were added. The reaction mixture was degassed by bubbling with $\mathrm{N}_{2}$. Afterwards, the Schlenk tube was sealed using a rubber septum and the reaction was stirred for $20 \mathrm{~h}$ at $75^{\circ} \mathrm{C}$ in an oil bath. After being cooled to room temperature, the reaction mixture was taken in DCM $(50 \mathrm{~mL})$ and the resultant organic layer was washed with water $(2 \times 100 \mathrm{~mL})$ using a separatory funnel. The organic phase was collected and the solvent was evaporated under reduced pressure. The solid residue was chromatographed on silica, eluting with 2:1 hexane-DCM, to afford the desired compound $3(74 \mathrm{mg}, 58 \%)$ as a greenish-red solid. ${ }^{1} \mathrm{H}$ NMR $(400 \mathrm{MHz}$, $\mathrm{CDCl}_{3}$ ): $\delta=11.19-11.01(\mathrm{~m}, 4 \mathrm{H}), 10.09$ (br. S, 4H), 9.65 (br. s, $\left.2 \mathrm{H}\right), 9.58$ (br. s, 2H), 5.64-5.55 (m, 2H), 5.05-4.83 (m, 4H), 2.64-2.55 (m, 4H), 2.29-2.10 (m, 12H), 2.11-2.01 (m, 4H), $1.89(\mathrm{~s}, 36 \mathrm{H}), 1.54-1.25(\mathrm{~m}$, $32 \mathrm{H}), 1.21(\mathrm{~d}, J=4.0 \mathrm{~Hz}, 36 \mathrm{H}), 1.19(\mathrm{~d}, J=8.0 \mathrm{~Hz}, 36 \mathrm{H}), 1.09(\mathrm{~d}, J=4.0 \mathrm{~Hz}, 12 \mathrm{H}), 1.04(\mathrm{~d}, J=4.0 \mathrm{~Hz}$, 12H), 0.88-0.83 ppm (m, 12H). ${ }^{13} \mathrm{C}\left\{{ }^{1} \mathrm{H}\right\}$ NMR $\left(126 \mathrm{MHz}, \mathrm{CDCl}_{3}\right): \delta=173.15,166.48,165.29,155.31$, $153.20,151.08,150.28,146.26,144.65,143.33,142.19,141.23,140.67,139.69,131.54,131.33,130.80$, $130.36,129.52,129.23,128.89,128.80,128.76,128.16,127.45,127.14,126.19,124.97,124.63,124.52$, $124.22,123.81,122.59,122.56,122.26,114.54,113.18,107.05,106.40,104.19,101.93,101.11,98.98$, $55.24,36.19,36.18,32.86,32.32,32.16,32.09,29.94,29.60,27.25,26.86,26.85,26.82,26.73,26.71,26.66$, $26.57,26.55,25.62,25.52,25.49,25.45,25.39,25.37,25.27,24.83,24.47,22.88,14.33$ ppm. HRMS (MALDI-TOF): $[\mathrm{M}]^{+}$Calculated for $\mathrm{C}_{166} \mathrm{H}_{214} \mathrm{~N}_{10} \mathrm{O}_{4} \mathrm{Si}_{4}, 2555.5645$; found, 2555.5665. 


\section{Synthesis of Building-block D:}

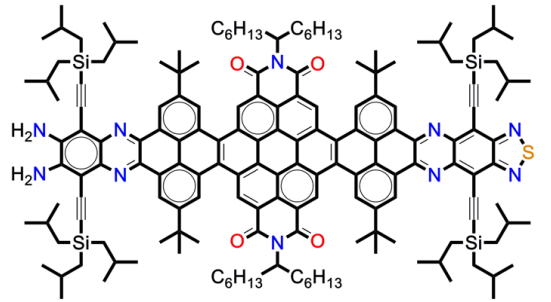

3

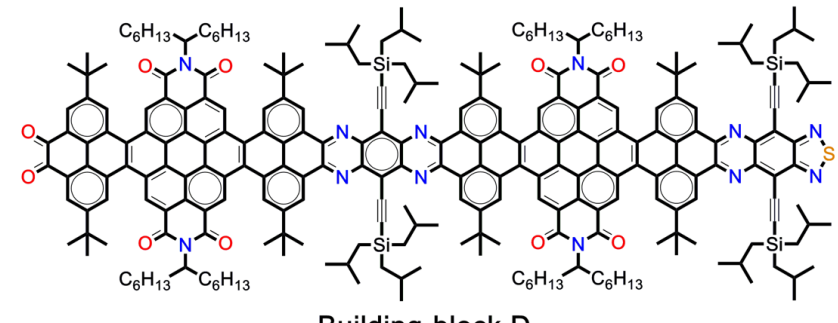

Building-block D

An oven dried Schlenk tube was charged with compound 3 (80 mg, $0.03 \mathrm{mmol}, 1$ eq.) and building-block A $(270 \mathrm{mg}, 0.19 \mathrm{mmol}, 6$ eq.). Subsequently, acetic acid $(13 \mathrm{~mL})$ and anhydrous chloroform $(20 \mathrm{~mL})$ were added. The Schlenk tube was sealed using a rubber septum and the reaction mixture was stirred for $48 \mathrm{~h}$ at 80 ${ }^{\circ} \mathrm{C}$ in an oil bath. After being cooled to room temperature, the reaction mixture was taken in DCM (100 mL) and the resultant organic layer was washed with water $(2 \times 100 \mathrm{~mL})$ using a separatory funnel. The organic phase was collected and the solvent was evaporated under reduced pressure. The solid residue was chromatographed on silica, eluting with 1:1 hexane-DCM, to afford the desired building-block $\mathbf{D}$ (85 mg, $69 \%$ ) as a dark-red solid. Thereafter, unreacted amount of building-block $\mathbf{A}$ was conveniently recovered by eluting the column with DCM. ${ }^{1} \mathrm{H}$ NMR $\left(400 \mathrm{MHz}, \mathrm{CDCl}_{3}\right): \delta=11.24-11.03(\mathrm{~m}, 6 \mathrm{H}), 10.91$ (br. S, $\left.1 \mathrm{H}\right)$, 10.86 (br. S, 1H), 10.26 (s, 4H), $10.10(\mathrm{~s}, 2 \mathrm{H}), 9.71$ (s, 2H), 9.67 (br. s, 4H), $9.52(\mathrm{~s}, 2 \mathrm{H}), 8.89$ (s, 2H), 5.69$5.55(\mathrm{~m}, 4 \mathrm{H}), 2.67-2.55(\mathrm{~m}, 8 \mathrm{H}), 2.35-2.19(\mathrm{~m}, 12 \mathrm{H}), 2.15-2.07(\mathrm{~m}, 8 \mathrm{H}), 1.98(\mathrm{~s}, 18 \mathrm{H}), 1.97(\mathrm{~s}, 18 \mathrm{H}), 1.91$ $(\mathrm{s}, 18 \mathrm{H}), 1.72(\mathrm{~s}, 18 \mathrm{H}), 1.58-1.31(\mathrm{~m}, 64 \mathrm{H}), 1.29(\mathrm{~d}, J=8.0 \mathrm{~Hz}, 12 \mathrm{H}), 1.26(\mathrm{~d}, J=4.0 \mathrm{~Hz}, 36 \mathrm{H}), 1.22(\mathrm{~d}, J=$ $8.0 \mathrm{~Hz}, 36 \mathrm{H}), 1.09(\mathrm{~d}, J=4.0 \mathrm{~Hz}, 12 \mathrm{H}), 0.92-0.83 \mathrm{ppm}(\mathrm{m}, 24 \mathrm{H}){ }^{13} \mathrm{C}\left\{{ }^{1} \mathrm{H}\right\}$ NMR $\left(126 \mathrm{MHz}, \mathrm{CDCl}_{3}\right): \delta=$ $180.77,166.20,166.02,164.99,164.81,155.08,152.10,150.91,150.85,145.96,145.44,145.31,142.64$, $142.60,141.94,134.82,131.10,130.89,130.01,129.71,129.65,129.32,129.22,128.83,128.75,128.63$, $128.47,128.43,128.31,127.92,127.80,127.05,126.56,125.98,125.95,124.56,124.45,124.22,124.05$, $123.69,123.66,122.37,122.28,122.10,121.52,114.31,112.98,112.94,102.63,101.68,55.15,55.08,53.40$, $36.06,35.96,35.73,32.63,32.58,32.13$, 31.92, 31.87, 31.85, 31.24, 29.36, 29.33, 27.03, 27.01, 26.64, 26.62, 25.46, 25.41, 25.33, 25.30, 25.28, 25.24, 22.65, 22.64, 14.09 ppm. HRMS (MALDI-TOF): [M] $]^{+}$Calculated for $\mathrm{C}_{264} \mathrm{H}_{312} \mathrm{~N}_{12} \mathrm{O}_{10} \mathrm{SSi}_{4}, 3955.3092$; found, 3955.3447 .

\section{Synthesis of Building-block E:}

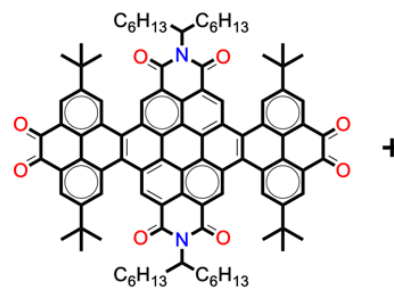

Building-block $A$

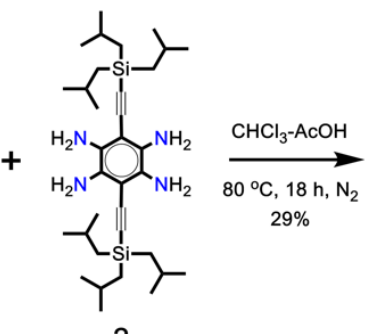

2

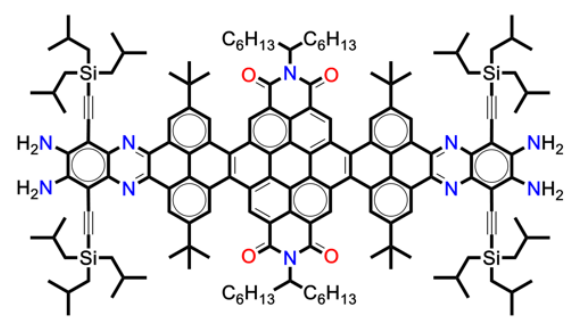

Building-block $\mathrm{E}$

An oven dried Schlenk tube was charged with building block A (86 mg, $0.06 \mathrm{mmol}, 1$ eq.) and tetraaminobenzene derivative $2(200 \mathrm{mg}, 0.34 \mathrm{mmol}, 5.6$ eq.). Subsequently, acetic acid $(2.5 \mathrm{~mL})$ and anhydrous chloroform $(5 \mathrm{~mL})$ were added. The reaction mixture was degassed by bubbling with $\mathrm{N}_{2}$. Afterwards, the Schlenk tube was sealed using a rubber septum and the reaction was stirred for $18 \mathrm{~h}$ at $80^{\circ} \mathrm{C}$ in an oil bath. After being cooled to room temperature, the reaction mixture was taken in DCM $(50 \mathrm{~mL})$ and the resultant organic layer was washed with water $(2 \times 100 \mathrm{~mL})$ using a separatory funnel. The organic phase was collected and the solvent was evaporated under reduced pressure. The solid residue was chromatographed on silica, eluting with 2:1 hexane-DCM, to afford the desired building-block $\mathbf{E}(44 \mathrm{mg}, 29 \%)$ as a dark-green solid. ${ }^{1} \mathrm{H}$ NMR (400 MHz, $\mathrm{CDCl}_{3}$ ): $\delta=11.16$ (br. S, 2H), 11.11 (br. S, 2H), 10.09 (s, 4H), 9.60 (s, 4H), 5.65-5.55 (m, 2H), 4.95 (br. S, 8H), 2.67-2.54 (m, 4H), 2.21-2.12 (m, 12H), 2.11-2.02 (m, 4H), 1.89 (s, 36H), 1.63-1.30 $(\mathrm{m}, 32 \mathrm{H}), 1.19(\mathrm{~d}, J=8.0 \mathrm{~Hz}, 72 \mathrm{H}), 1.04(\mathrm{~d}, J=8.0 \mathrm{~Hz}, 24 \mathrm{H}), 0.89-0.83 \mathrm{ppm}(\mathrm{m}, 12 \mathrm{H}) .{ }^{13} \mathrm{C}\left\{{ }^{1} \mathrm{H}\right\} \mathrm{NMR}(126$ $\left.\mathrm{MHz}, \mathrm{CDCl}_{3}\right): \delta=166.33,165.15,149.99,143.06,140.50,139.44,131.73,130.98,130.08,128.92,128.65$, $128.00,127.14,124.72,124.08,123.50,122.39,122.24,121.91,121.26,106.80,104.01,100.90,54.93$, $35.94,32.65,32.10,31.87,29.72,29.39,27.02,26.62,25.40,25.39,22.66,14.10$ ppm. HRMS (MALDITOF): [M] $]^{+}$Calculated for $\mathrm{C}_{166} \mathrm{H}_{218} \mathrm{~N}_{10} \mathrm{O}_{4} \mathrm{Si}_{4}, 2527.6237$; found, 2527.6224 . 

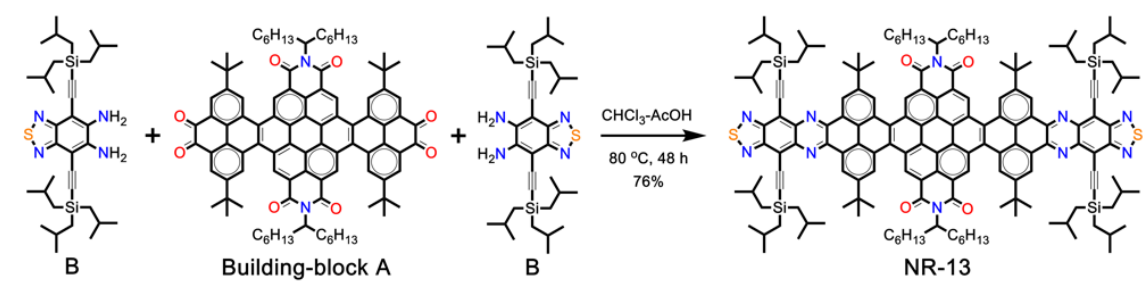

The tetraketone-based building-block A $(100 \quad \mathrm{mg}, \quad 0.07 \quad \mathrm{mmol}, \quad 1 \quad$ eq. $)$ and 4,7bis((triisobutylsilyl)ethynyl)benzo[c][1,2,5]thiadiazole B (103 $\mathrm{mg}, 0.17 \mathrm{mmol}, 2.4$ eq.) were taken in a reaction vial. Subsequently, acetic acid $(2 \mathrm{~mL})$ and anhydrous chloroform $(4 \mathrm{~mL})$ were added. The reaction vial was sealed and the reaction mixture was stirred at $80{ }^{\circ} \mathrm{C}$ for $48 \mathrm{~h}$. After being cooled to room temperature, the reaction mixture was poured in chloroform $(100 \mathrm{~mL})$ and the resultant organic layer was washed with water $(2 \times 200 \mathrm{~mL})$. The organic layer was collected and concentrated under reduced pressure to obtain the crude product, which was purified by silica-gel column chromatography (2:1 hexane-DCM) to afford NR-13 (137 mg, 76\%) as a purple solid. Crystals suitable for X-ray crystallography were obtained by a slow diffusion of methanol into a chloroform solution of NR-13. ${ }^{1} \mathrm{H}$ NMR (400 MHz, $\left.\mathrm{CDCl}_{3}\right): \delta=11.11$ (br. S, 2H), 11.06 (br. S, 2H), 10.09 (s, 4H), $9.64(\mathrm{~s}, 4 \mathrm{H}), 5.64-5.55(\mathrm{~m}, 2 \mathrm{H}), 2.65-2.54(\mathrm{~m}, 4 \mathrm{H}), 2.27-2.15$ (m, $12 \mathrm{H}), 2.13-2.02(\mathrm{~m}, 4 \mathrm{H}), 1.89(\mathrm{~s}, 36 \mathrm{H}), 1.55-1.25(\mathrm{~m}, 32 \mathrm{H}), 1.22(\mathrm{~d}, J=4.0 \mathrm{~Hz}, 72 \mathrm{H}), 1.09(\mathrm{~d}, J=4.0 \mathrm{~Hz}$, 24H), $0.86 \mathrm{ppm}(\mathrm{t}, J=8.0 \mathrm{~Hz}, 12 \mathrm{H}) .{ }^{13} \mathrm{C}\left\{{ }^{1} \mathrm{H}\right\} \mathrm{NMR}\left(126 \mathrm{MHz}, \mathrm{CDCl}_{3}\right): \delta=166.40,165.17,155.32,151.14$, $146.20,142.18,131.33,131.13,129.56,128.87,128.69$, 127.23, 126.22, 124.71, 124.44, 123.88, 122.58, $122.39,121.71,114.56,113.23,101.92,55.31,36.20,32.85,32.16,32.09,29.59,27.26,26.87,25.52,25.49$, 22.88, 14.33 ppm. HRMS (MALDI-TOF): $[\mathrm{M}+\mathrm{H}]^{+}$Calculated for $\mathrm{C}_{166} \mathrm{H}_{211} \mathrm{~N}_{10} \mathrm{O}_{4} \mathrm{~S}_{2} \mathrm{Si}_{4}, 2584.5129$; found, 2584.5086.

\section{Synthesis of NR-33:}
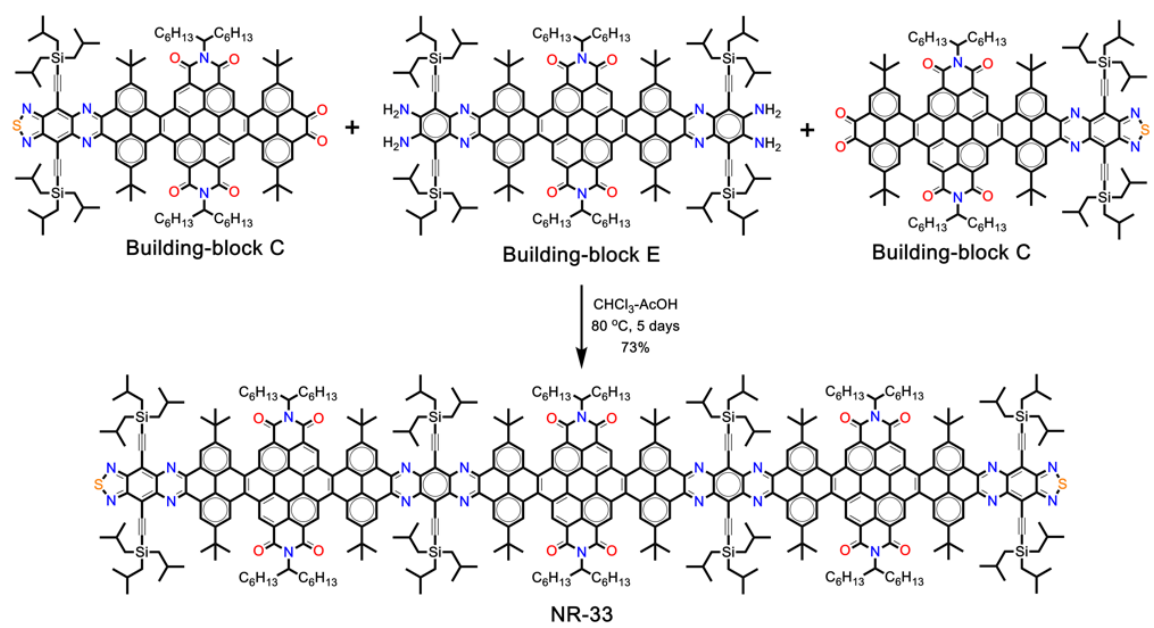

The tetra-amine-based building-block $\mathbf{E}$ (26 mg, $0.01 \mathrm{mmol}, 1$ eq.) and building-block $\mathbf{C}$ (100 mg, 0.05 mmol, 5 eq.) were taken in a reaction vial. Subsequently, acetic acid $(1.5 \mathrm{~mL})$ and anhydrous chloroform (3 $\mathrm{mL}$ ) were added. The reaction vial was sealed and the reaction mixture was stirred at $80^{\circ} \mathrm{C}$ for 5 days. After being cooled to room temperature, the reaction mixture was taken in chloroform $(100 \mathrm{~mL})$ and the resultant organic layer was washed with water $(2 \times 200 \mathrm{~mL})$. The organic layer was collected and concentrated under reduced pressure to obtain the crude product, which was purified by silica-gel column chromatography $(2: 1$ hexane-DCM) to afford NR-33 (49 $\mathrm{mg}, 73 \%$ ) as a purple solid. Thereafter, unreacted building-block C (57 $\mathrm{mg}, 57 \%$ ) was recovered from the column by eluting the column with $1: 1$ hexane-DCM mixture. ${ }^{1} \mathrm{H}$ NMR (400 MHz, $\mathrm{CDCl}_{3}$ ): $\delta=11.26-11.05$ (br. m, 12H), 10.28 (S, 8H), 10.12 (s, 4H), $9.74(\mathrm{~s}, 4 \mathrm{H}), 9.73(\mathrm{~s}, 4 \mathrm{H})$, $9.67(\mathrm{~s}, 4 \mathrm{H}), 5.70-5.58(\mathrm{~m}, 6 \mathrm{H}), 2.70-2.59(\mathrm{~m}, 12 \mathrm{H}), 2.37-2.29(\mathrm{~m}, 12 \mathrm{H}), 2.28-2.21(\mathrm{~m}, 12 \mathrm{H}), 2.17-2.08(\mathrm{~m}$, $12 \mathrm{H}), 2.01(\mathrm{~s}, 36 \mathrm{H}), 2.00(\mathrm{~s}, 36 \mathrm{H}), 1.92(\mathrm{~s}, 36 \mathrm{H}), 1.59-1.33(\mathrm{~m}, 96 \mathrm{H}), 1.32(\mathrm{~d}, J=4.0 \mathrm{~Hz}, 24 \mathrm{H}), 1.29(\mathrm{~d}, J=$ $4.0 \mathrm{~Hz}, 72 \mathrm{H}), 1.23(\mathrm{~d}, J=8.0 \mathrm{~Hz}, 72 \mathrm{H}), 1.10(\mathrm{~d}, J=8.0 \mathrm{~Hz}, 24 \mathrm{H}), 0.93-0.85 \mathrm{ppm}(\mathrm{m}, 36 \mathrm{H}) .{ }^{13} \mathrm{C}\left\{{ }^{1} \mathrm{H}\right\} \mathrm{NMR}$ $\left(126 \mathrm{MHz}, \mathrm{CDCl}_{3}\right): \delta={ }^{13} \mathrm{C}$ NMR $\left(126 \mathrm{MHz}, \mathrm{CDCl}_{3}\right) \delta 166.23,165.02,155.08,150.91,150.85,145.98$, $145.44,145.41,142.64,141.94,131.70,131.11,130.90,129.68,129.33,128.77,128.64,128.47,127.07$, $125.98,124.47,124.24,123.68,122.39,122.10,121.50,114.32,112.98,112.91,102.66,101.69,55.09$, $36.08,35.96,32.64,32.16,31.93,31.90,31.87,29.70,29.40,29.37,27.07,27.04,26.66,26.63,25.47,25.43$, 25.40, 25.32, 25.28, 25.25, 22.68, 22.66, 14.12, 14.11 ppm. HRMS (MALDI-TOF): $[\mathrm{M}+\mathrm{Ag}]^{+}$Calculated for $\mathrm{C}_{430} \mathrm{H}_{522} \mathrm{AgN}_{22} \mathrm{O}_{12} \mathrm{~S}_{2} \mathrm{Si}_{8}, 6586.7531$; found, 6586.7381. 


\section{Synthesis of NR-53:}
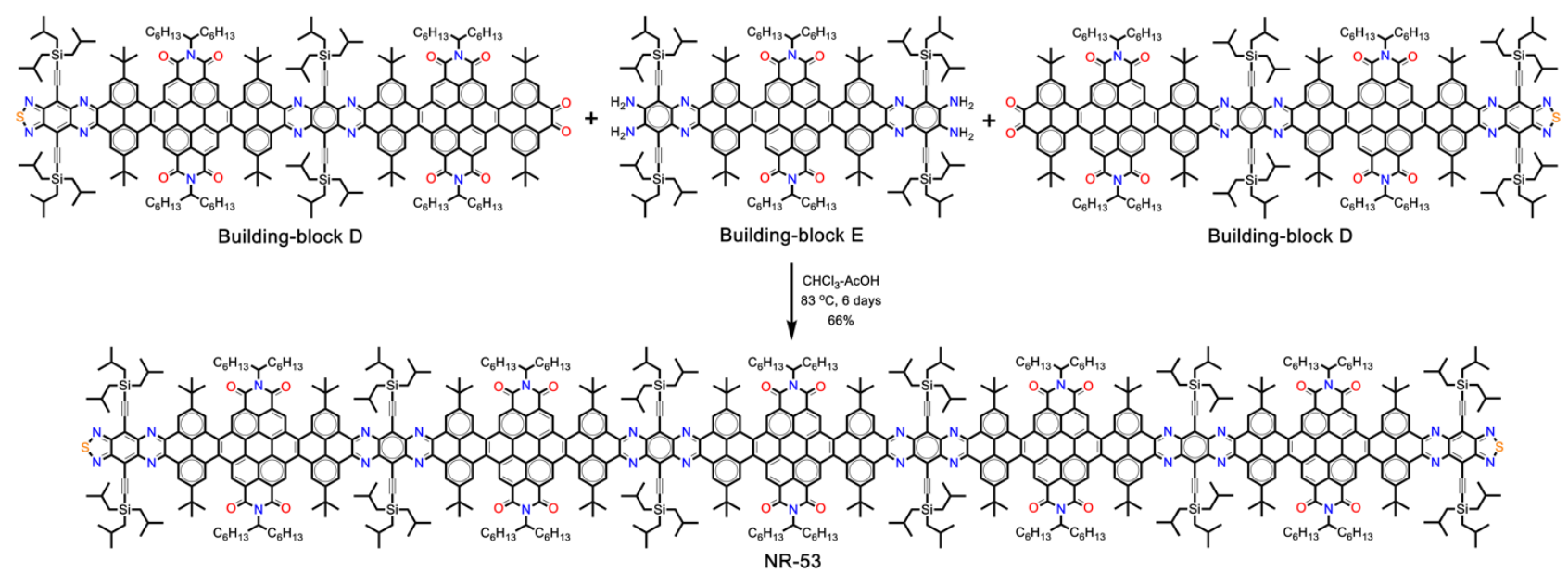

The NR-53 has been synthesized following the same procedure as explained above for NR-13 and NR-33 using the building-block $\mathbf{E}$ (10 $\mathrm{mg}, 0.004 \mathrm{mmol}, 1$ eq.), building-block $\mathbf{D}$ (50 $\mathrm{mg}, 0.013 \mathrm{mmol}, 3$ eq.), acetic acid $(2 \mathrm{~mL})$, and anhydrous chloroform $(4 \mathrm{~mL})$ in a sealed reaction vial. The reaction mixture was stirred at $83{ }^{\circ} \mathrm{C}$ for 6 days. The crude product was purified by silica-gel column chromatography (1:1 hexane-DCM) to afford NR-53 (27 mg, 66\%) as a purple solid. Subsequently, unreacted building-block D (25 mg, 50\%) was recovered from the column by eluting the column with $2: 1 \mathrm{DCM}-$ hexane mixture. ${ }^{1} \mathrm{H}$ NMR $(400 \mathrm{MHz}$, $\mathrm{CDCl}_{3}$ ): $\delta=11.29-11.06$ (br. m, 20H), 10.30 (br. S, 16H), 10.12 (br. s, 4H), 9.76 (br. s, 16H), 9.68 (br. s, 4H), 5.73-5.58 (m, 10H), 2.75-2.59 (m, 20H), 2.37-2.23 (m, 36H), 2.18-2.10 (m, 20H), $2.02(\mathrm{~s}, 108 \mathrm{H}), 2.00(\mathrm{~s}$, $36 \mathrm{H}), 1.92(\mathrm{~s}, 36 \mathrm{H}), 1.60-1.34(\mathrm{~m}, 160 \mathrm{H}), 1.34-1.27(\mathrm{~m}, 192 \mathrm{H}), 1.23(\mathrm{~d}, J=8.0 \mathrm{~Hz}, 72 \mathrm{H}), 1.11(\mathrm{~d}, J=8.0$ $\mathrm{Hz}, 24 \mathrm{H}), 0.93-0.85 \mathrm{ppm}(\mathrm{m}, 60 \mathrm{H}) .{ }^{13} \mathrm{C}\left\{{ }^{1} \mathrm{H}\right\} \mathrm{NMR}\left(126 \mathrm{MHz}, \mathrm{CDCl}_{3}\right): \delta=166.24,165.04,155.08,150.86$, $145.97,145.43,142.64,141.94,131.72,130.96,129.69,129.32,128.77,128.63,128.47,127.06,125.98$, $124.47,124.25,123.69,122.41,122.10,121.51,114.32,112.98,112.91,102.67,101.69,55.09,36.09,36.07$, 35.96, 32.65, 32.16, 31.92, 31.90, 31.87, 29.69, 29.65, 29.40, 29.37, 27.07, 27.04, 26.66, 26.62, 25.44, 25.32, $25.28, \quad 25.25, \quad 22.68, \quad 22.66, \quad 14.13, \quad 14.10 . \quad \mathrm{MS} \quad$ (MALDI-TOF): $[\mathrm{M}+\mathrm{Ag}]^{+}$Calculated for $\mathrm{C}_{694} \mathrm{H}_{83} \mathrm{AgN}_{34} \mathrm{O}_{20} \mathrm{~S}_{2} \mathrm{Si}_{12}, 10481.123$; found, 10480.798 . 

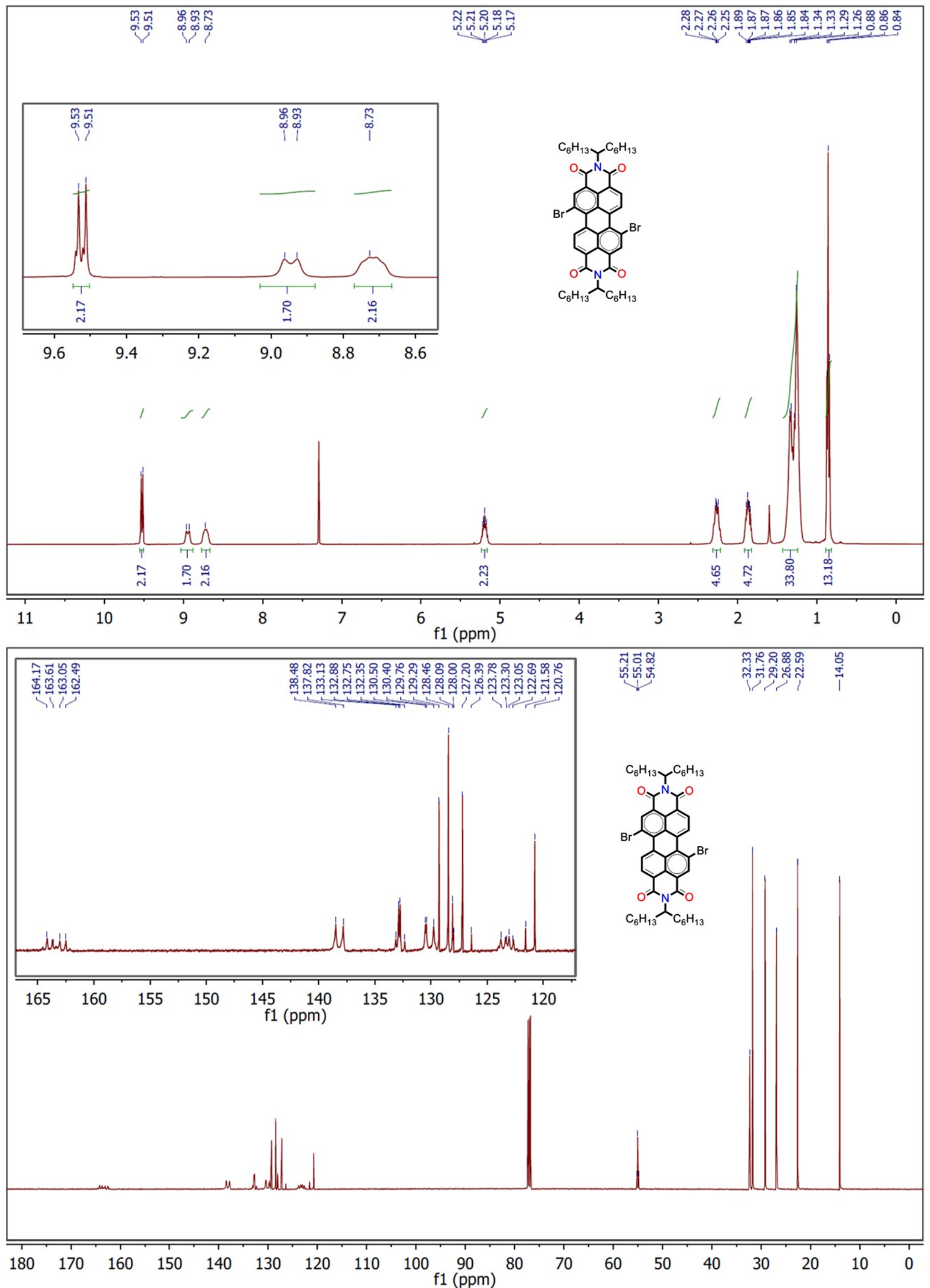

Figure S11. ${ }^{1} \mathrm{H}$ and ${ }^{13} \mathrm{C}$ NMR spectra of compound 7. 

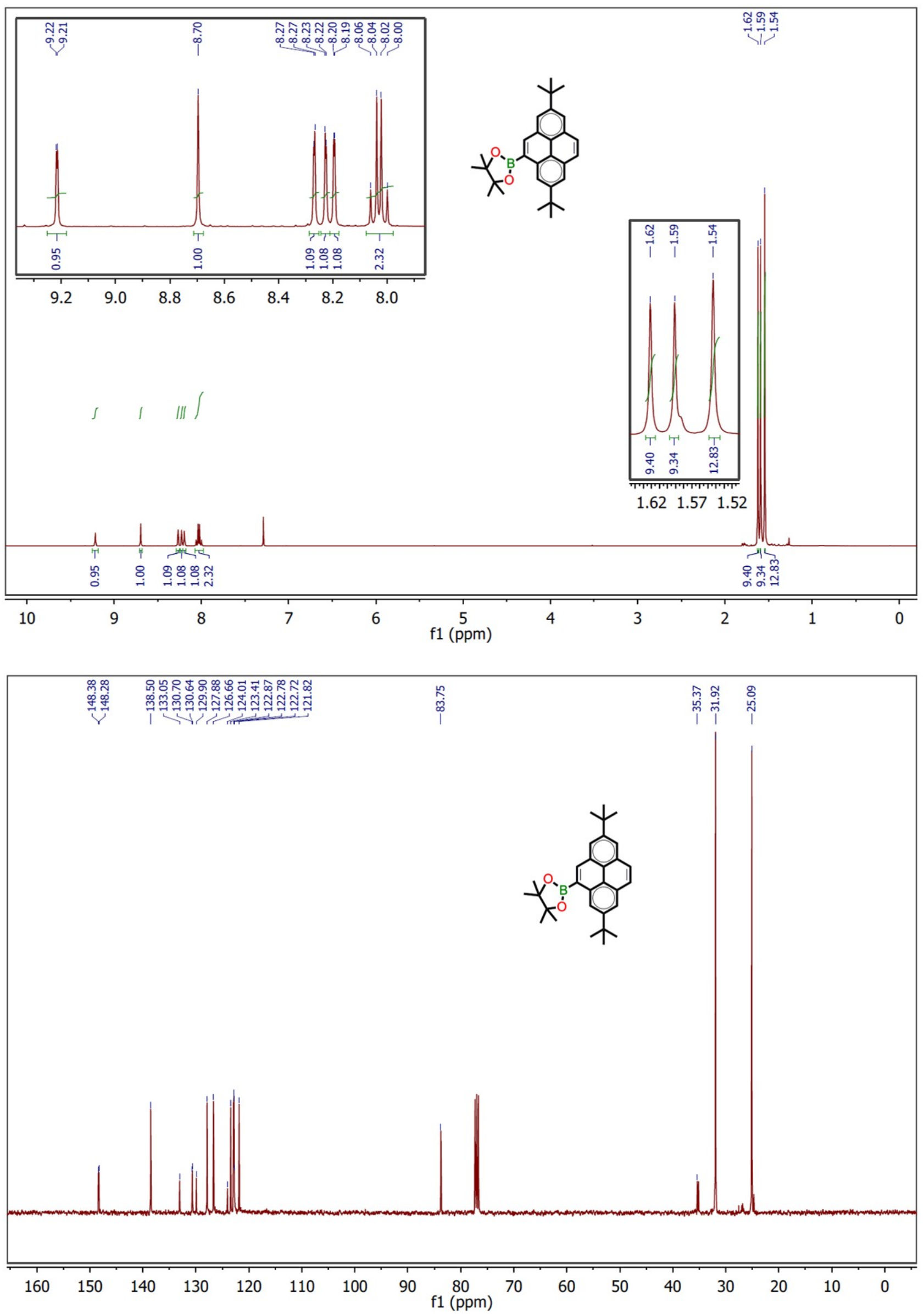

Figure S12. ${ }^{1} \mathrm{H}$ and ${ }^{13} \mathrm{C}$ NMR spectra of compound 8. 


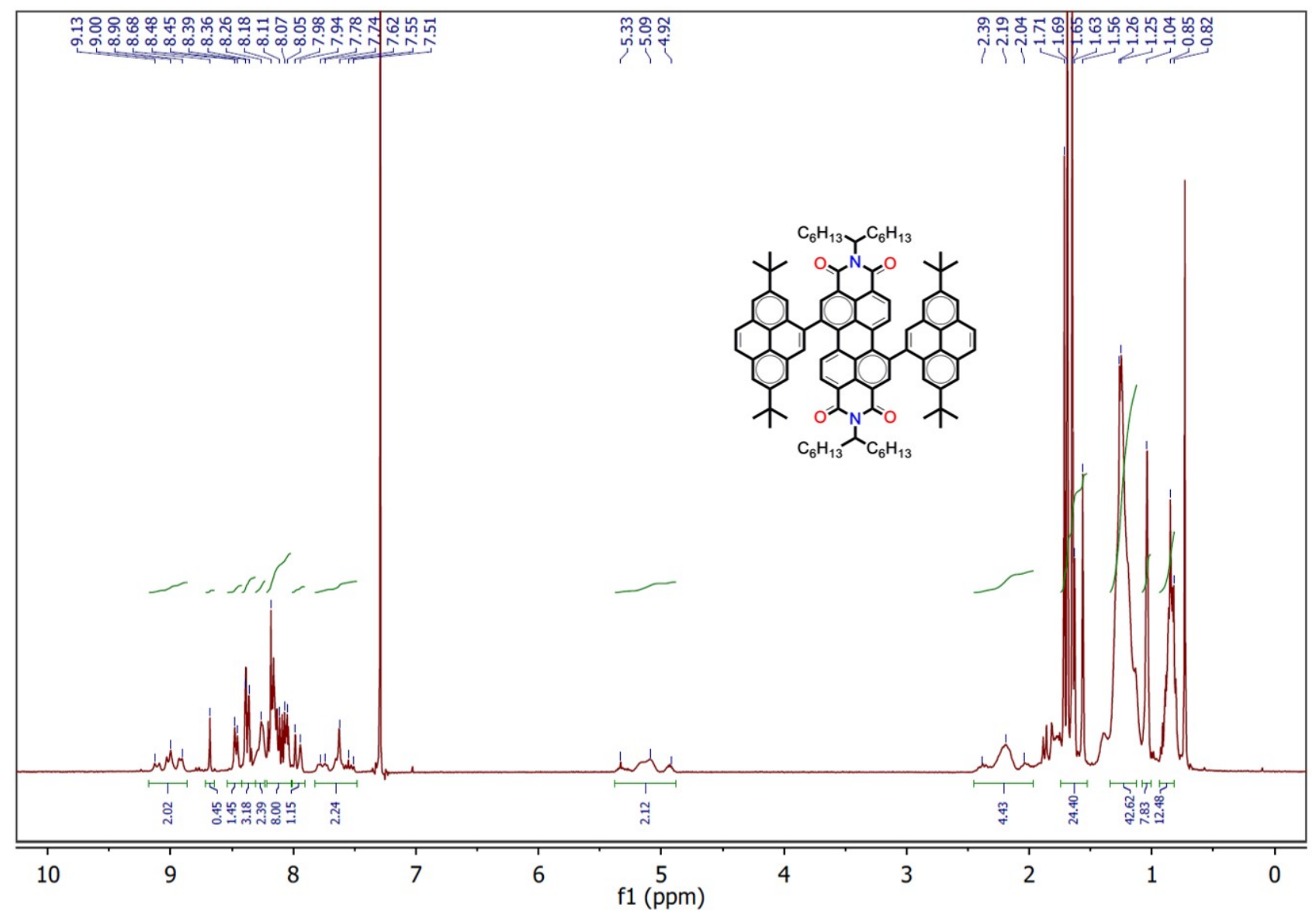

Figure S13. ${ }^{1} \mathrm{H}$ NMR spectrum of compound 9. 


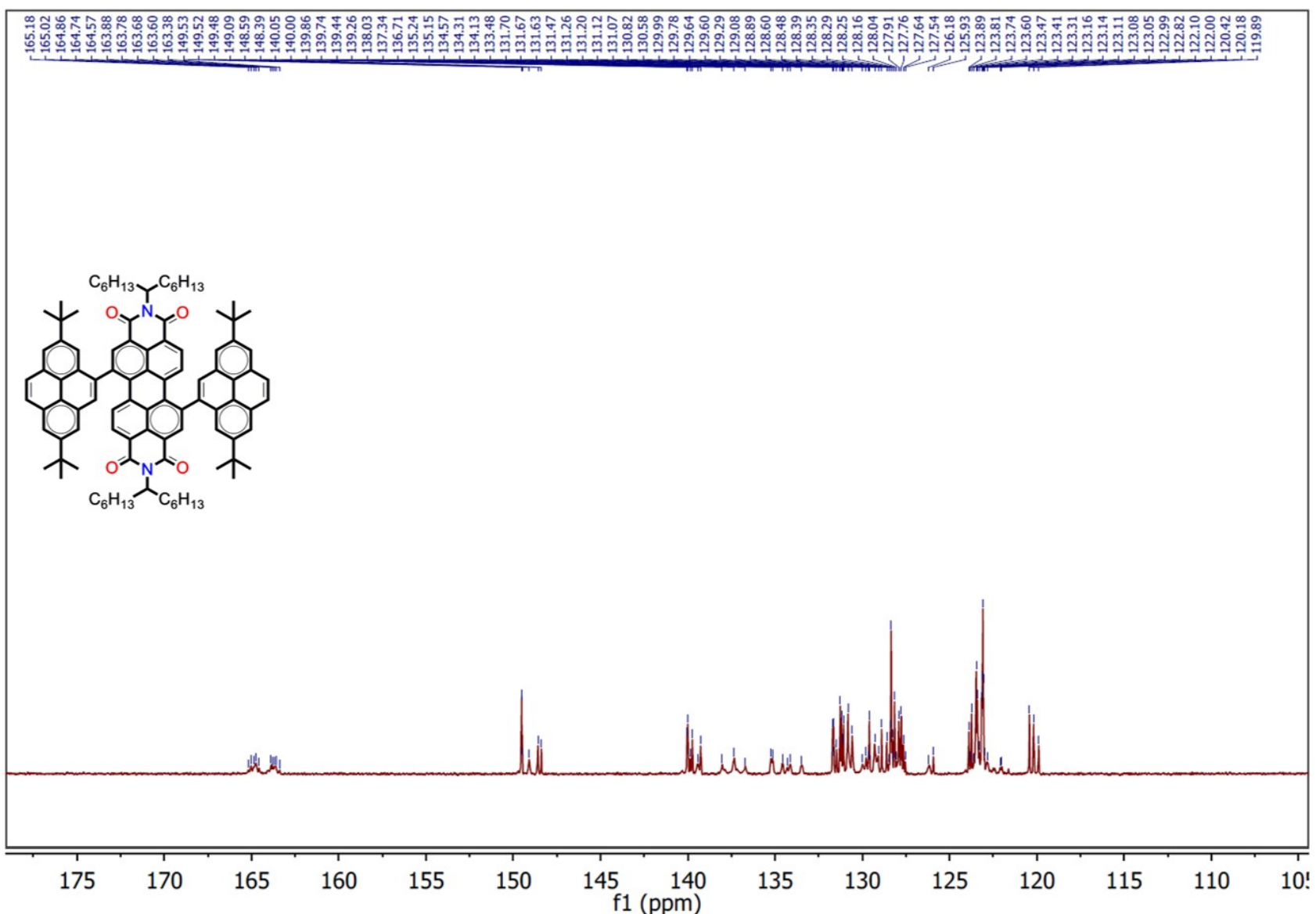

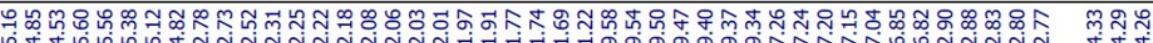

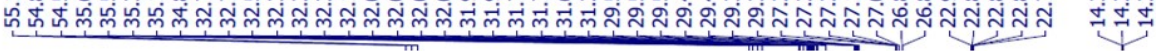

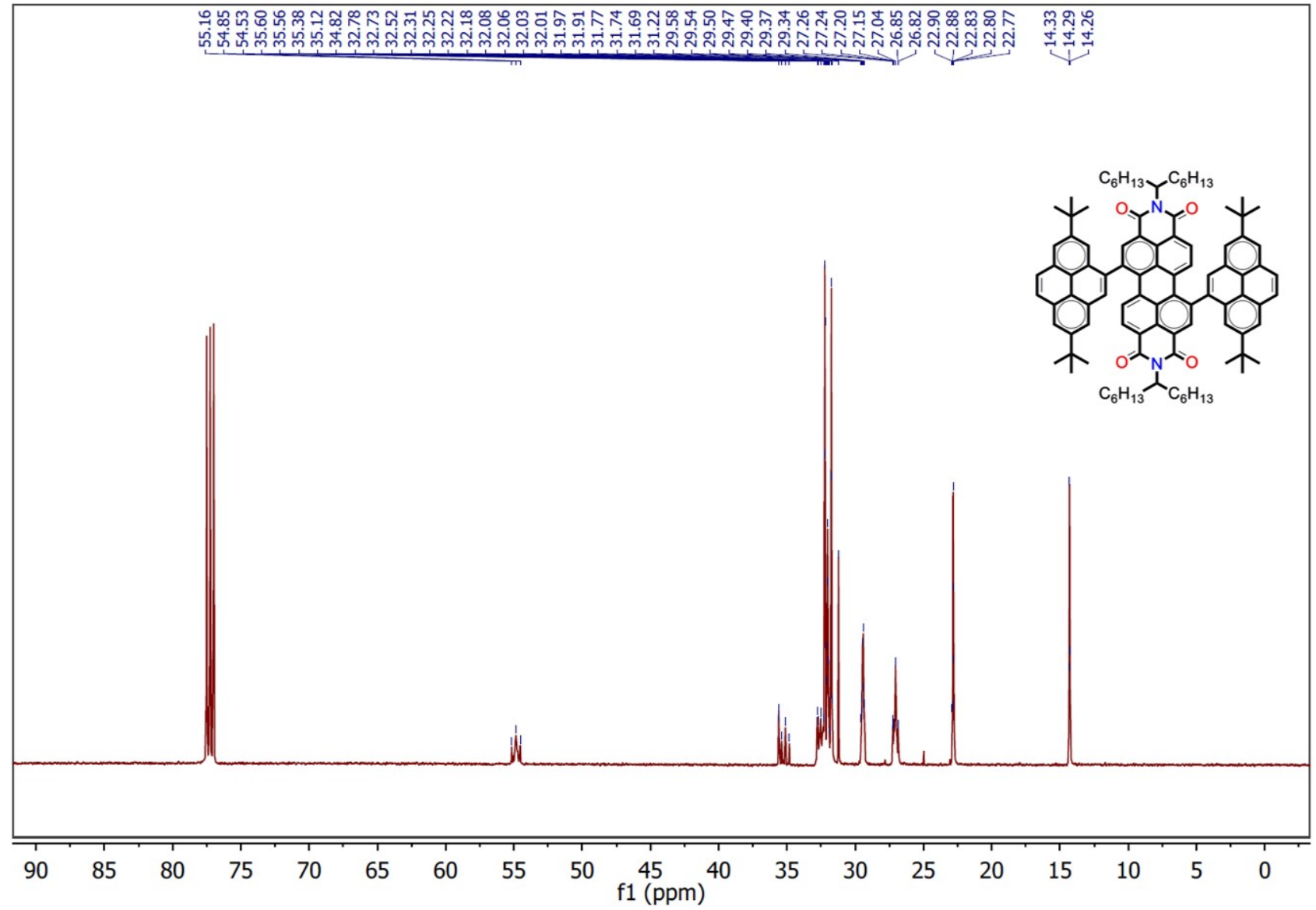

Figure S14. Aromatic (top) and aliphatic (bottom) parts of the ${ }^{13} \mathrm{C}$ NMR spectrum of compound 9. 

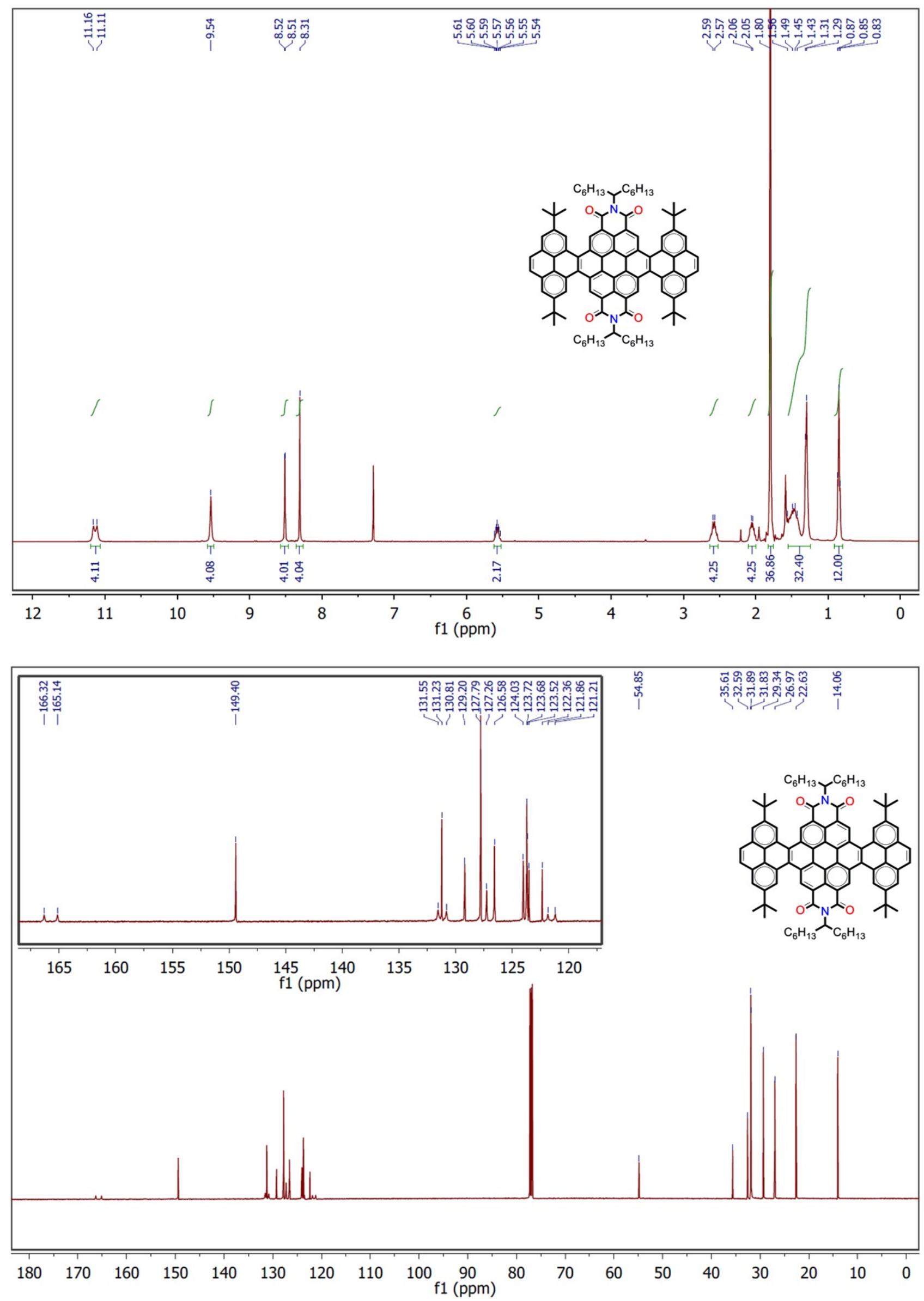

Figure S15. ${ }^{1} \mathrm{H}$ and ${ }^{13} \mathrm{C}$ NMR spectra of compound 1. 

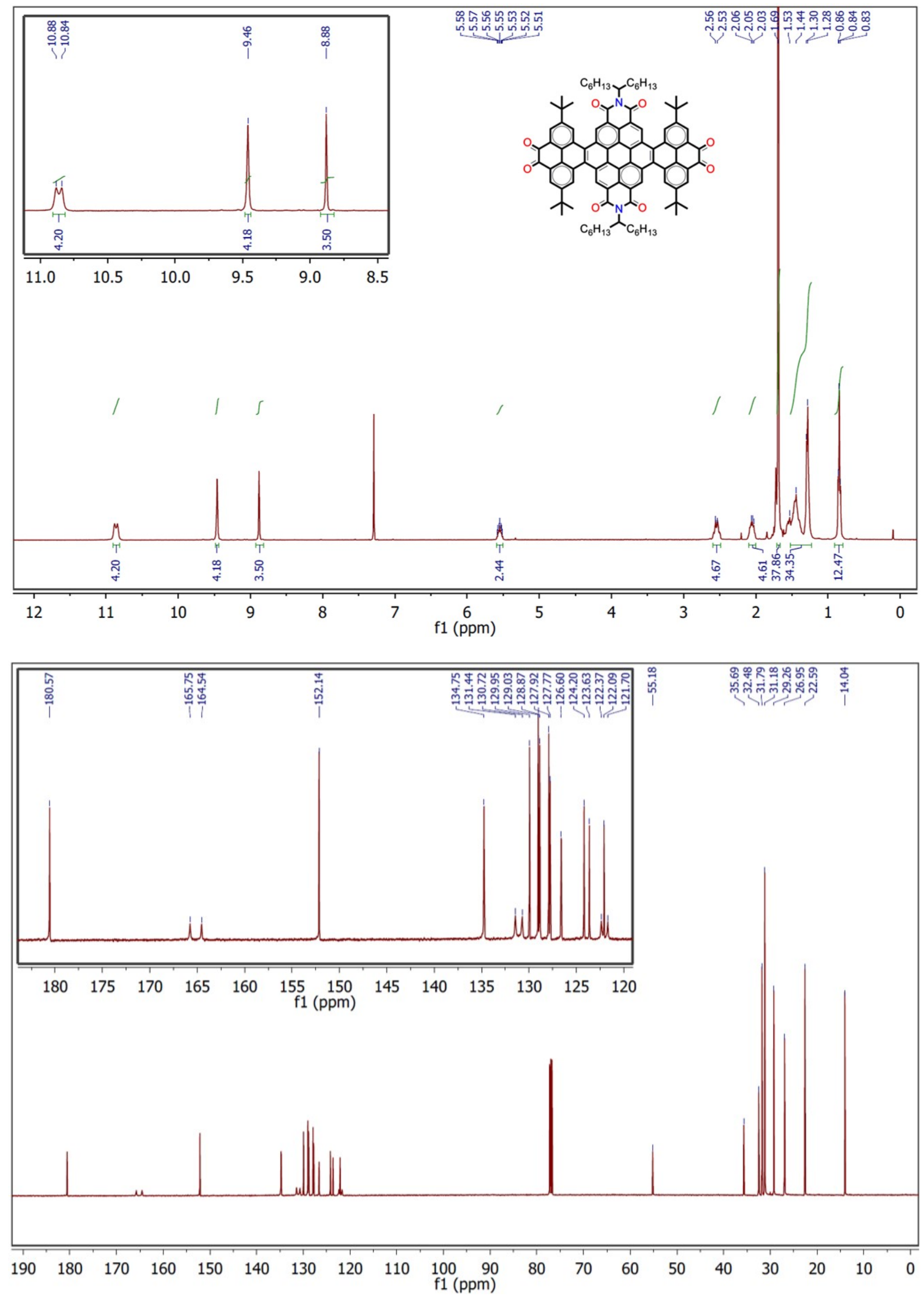

Figure S16. ${ }^{1} \mathrm{H}$ and ${ }^{13} \mathrm{C}$ NMR spectra of building block A. 

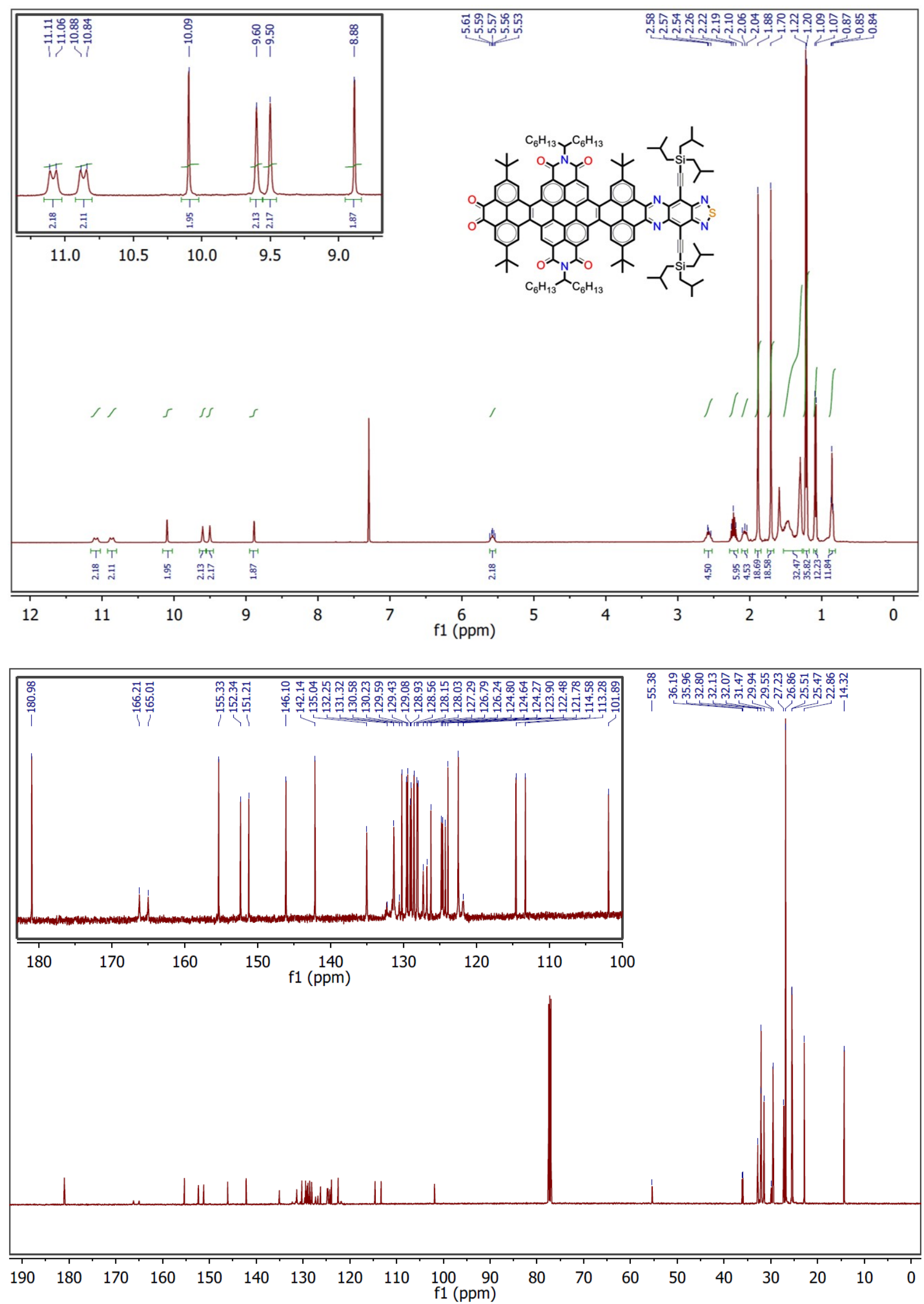

Figure S17. ${ }^{1} \mathrm{H}$ and ${ }^{13} \mathrm{C}$ NMR spectra of building block $\mathrm{C}$. 

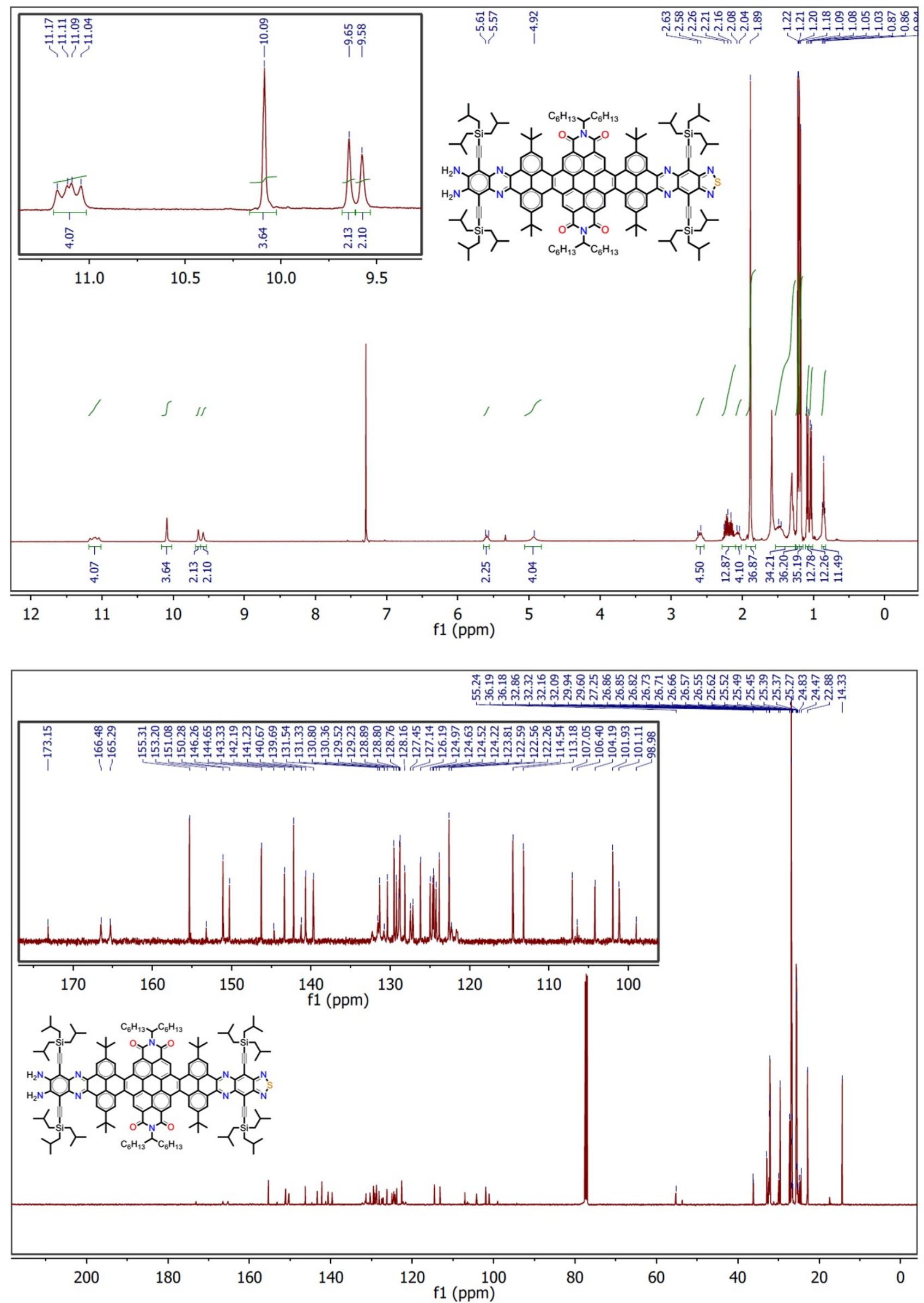

Figure S18. ${ }^{1} \mathrm{H}$ and ${ }^{13} \mathrm{C}$ NMR spectra of compound 3. 

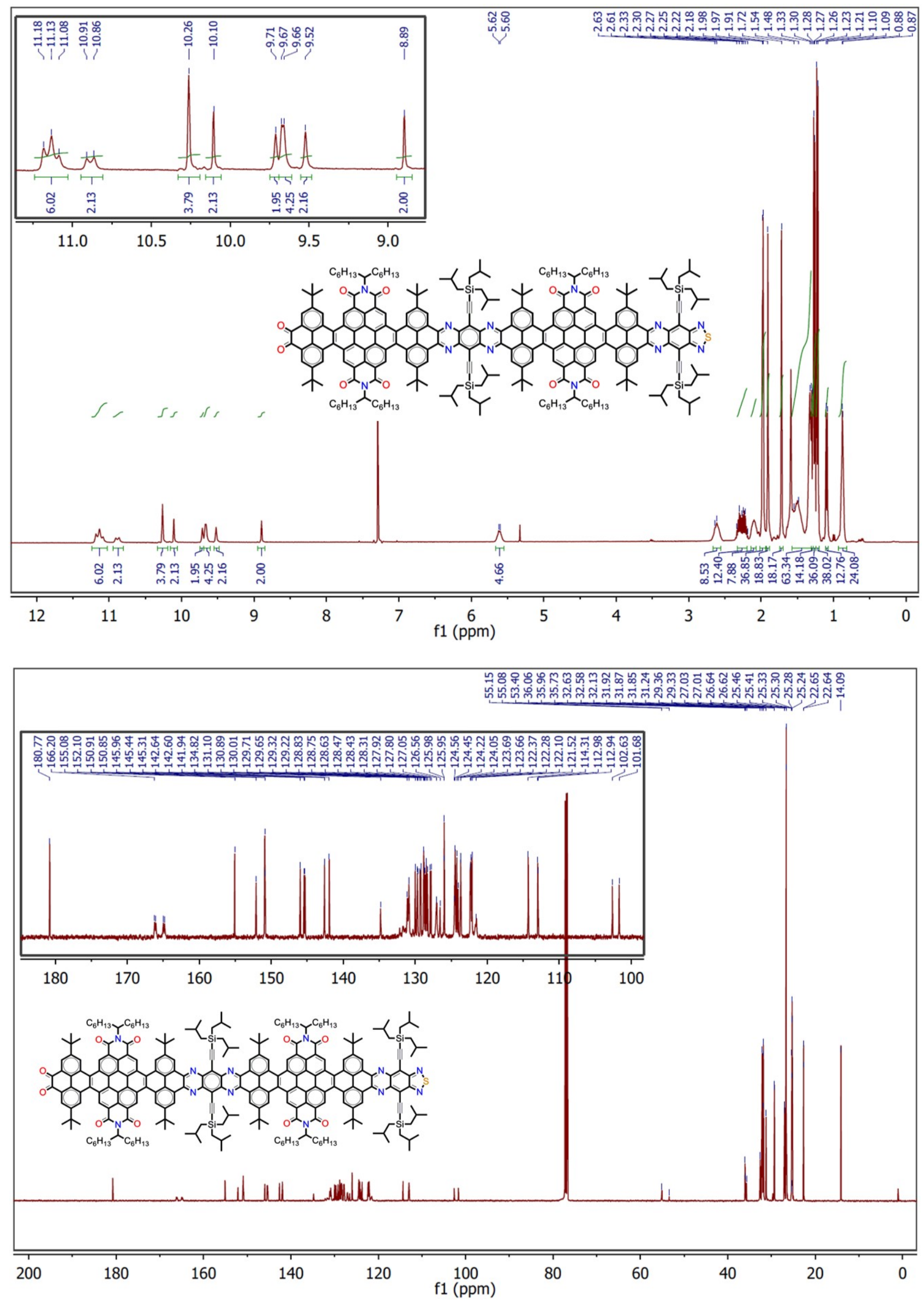

Figure S19. ${ }^{1} \mathrm{H}$ and ${ }^{13} \mathrm{C}$ NMR spectra of building block D. 

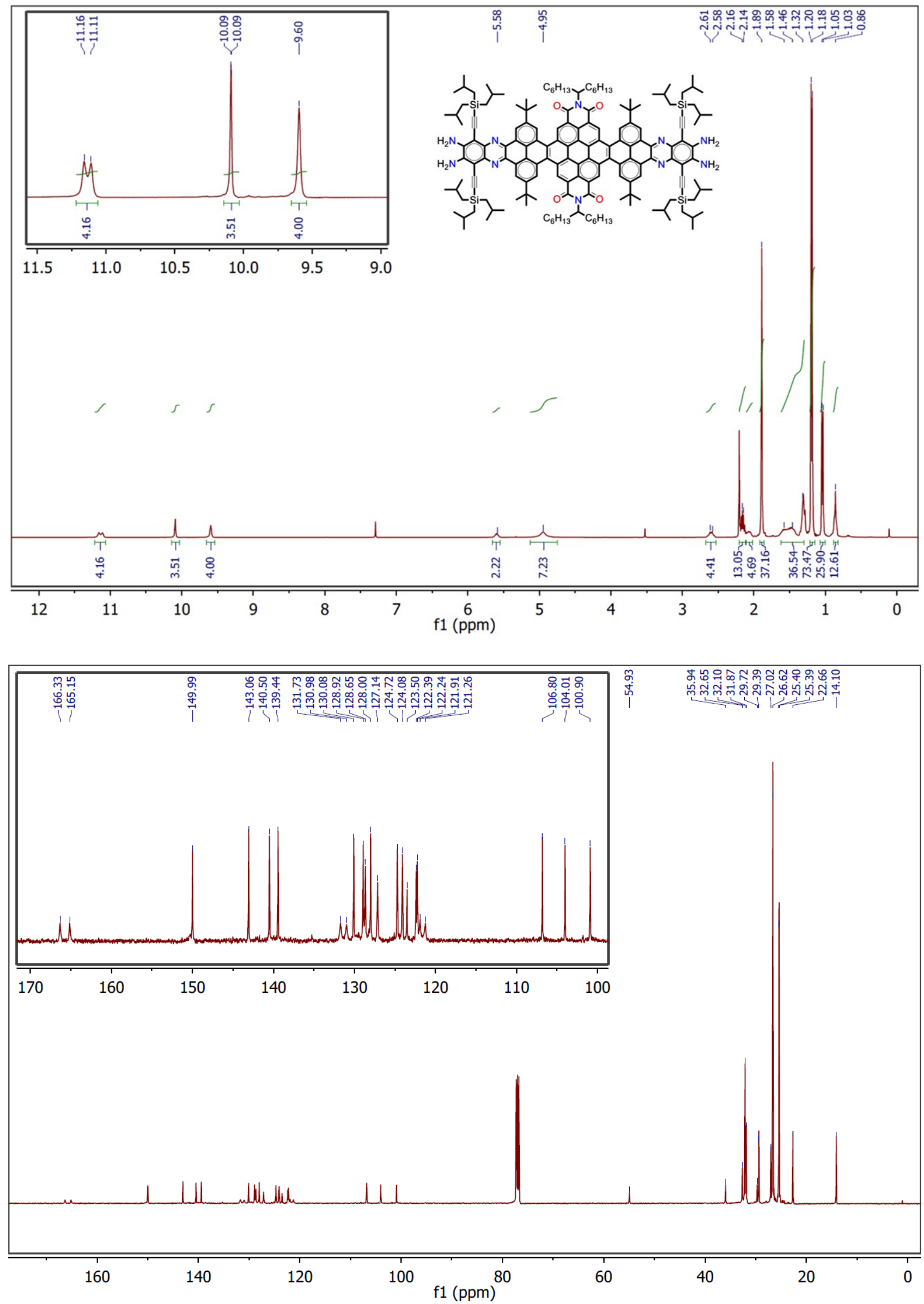

Figure S20. ${ }^{1} \mathrm{H}$ and ${ }^{13} \mathrm{C}$ NMR spectra of building block E. 

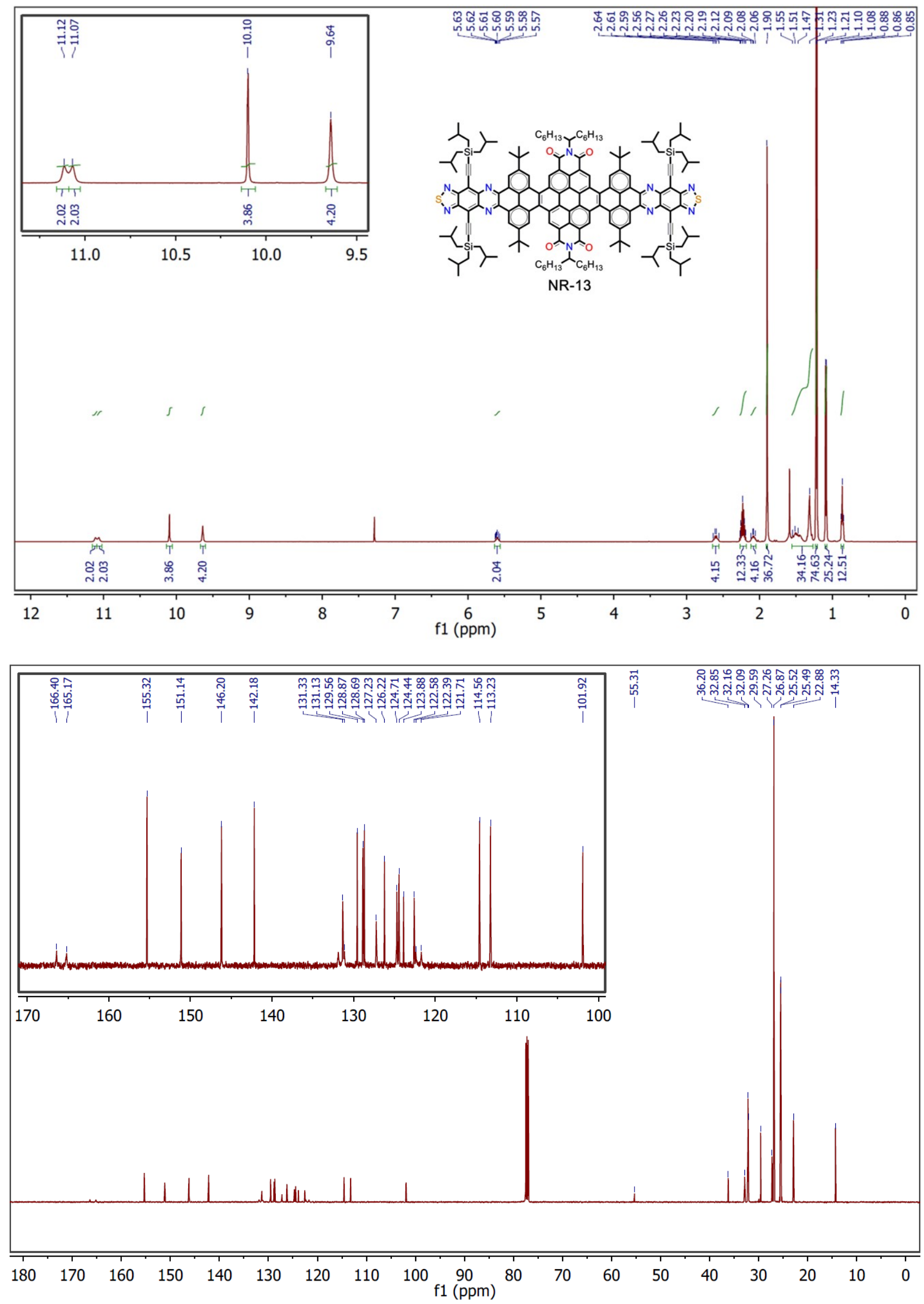

Figure S21. ${ }^{1} \mathrm{H}$ and ${ }^{13} \mathrm{C}$ NMR spectra of NR-13. 

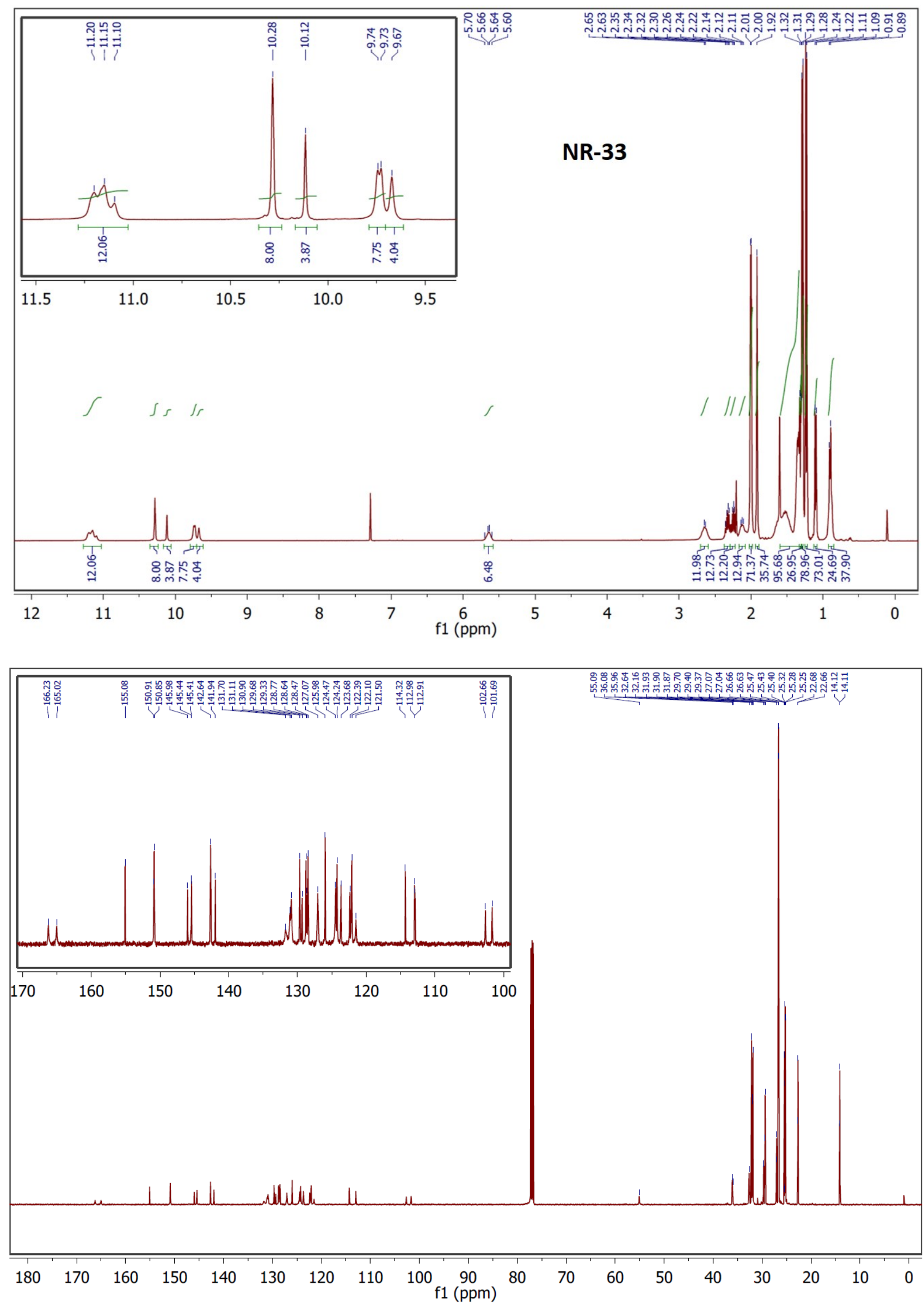

Figure S22. ${ }^{1} \mathrm{H}$ and ${ }^{13} \mathrm{C}$ NMR spectra of NR-33. 

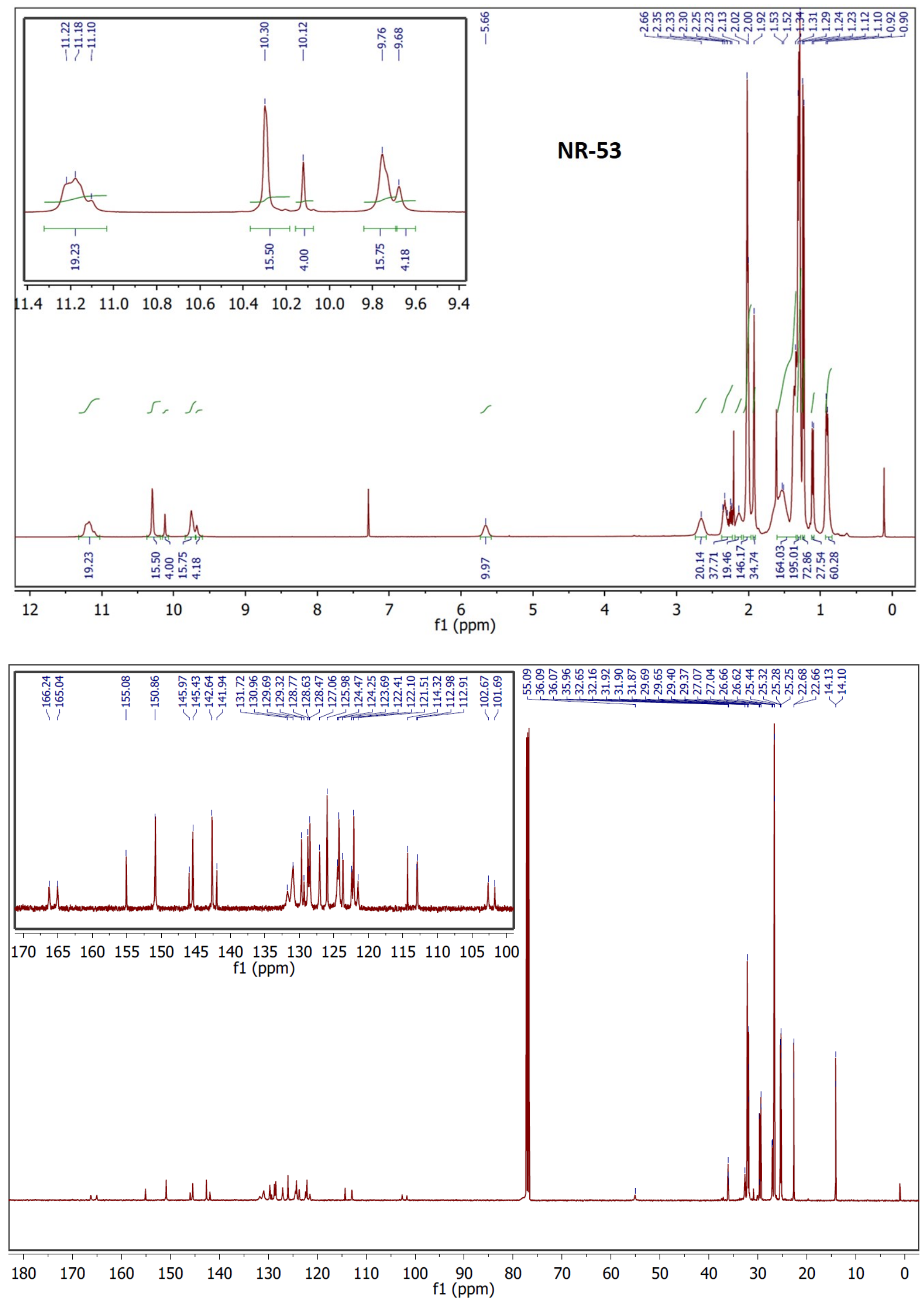

Figure S23. ${ }^{1} \mathrm{H}$ and ${ }^{13} \mathrm{C}$ NMR spectra of NR-53. 

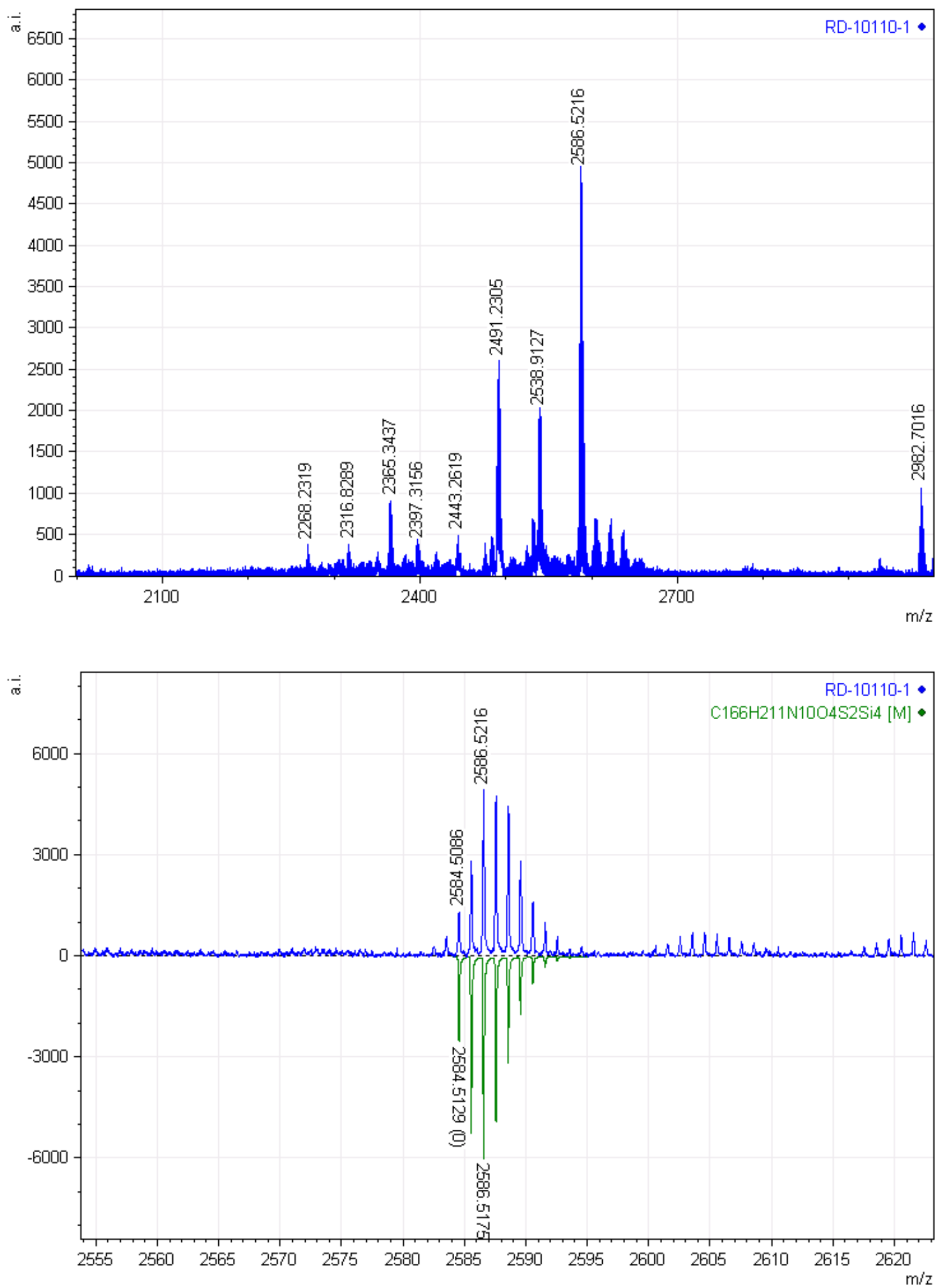

Figure S24. Full (top) and zoomed (bottom) MALDI-TOF mass spectrum of NR-13. 

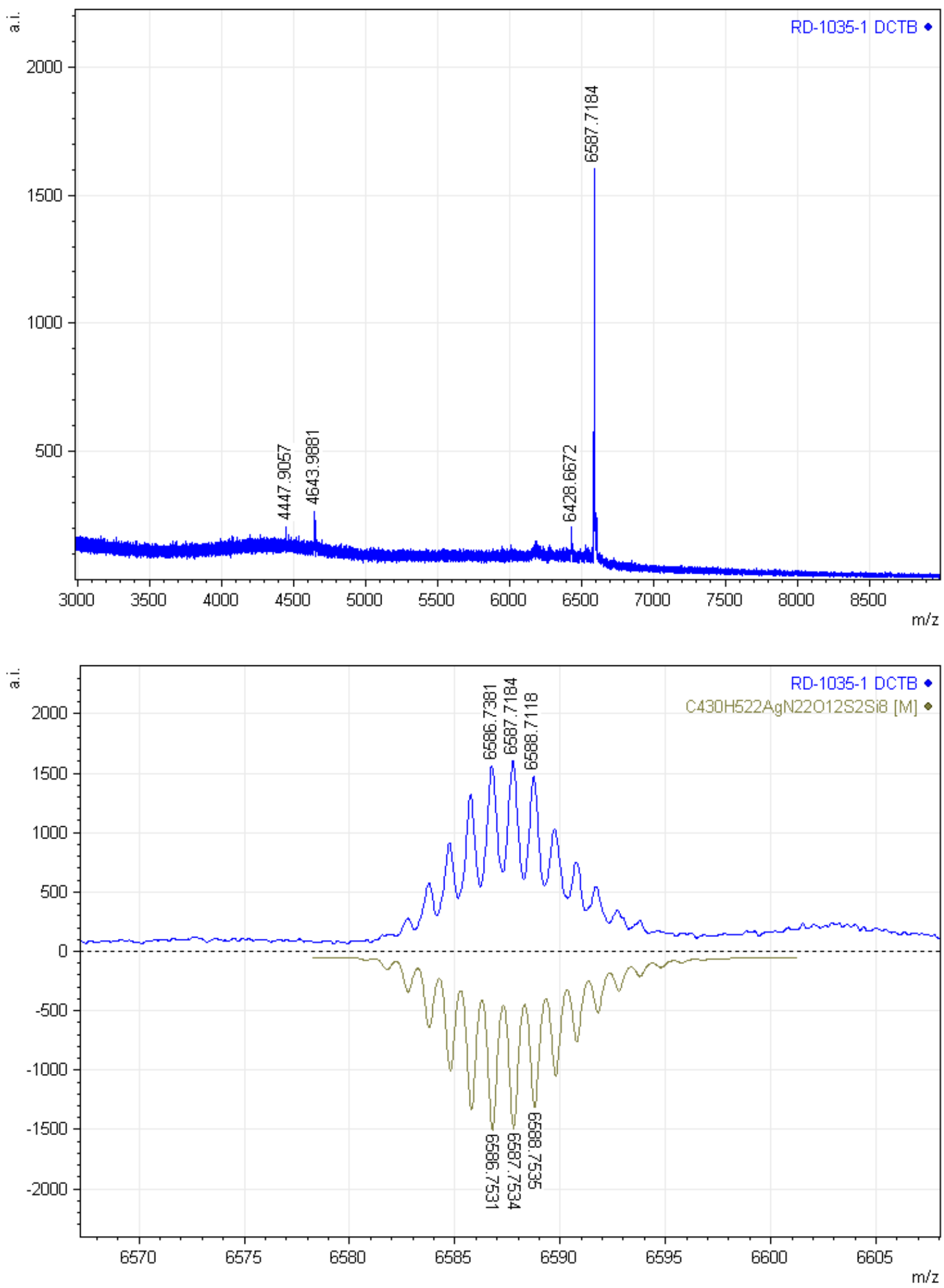

Figure S25. Full (top) and zoomed (bottom) MALDI-TOF mass spectrum of NR-33. 


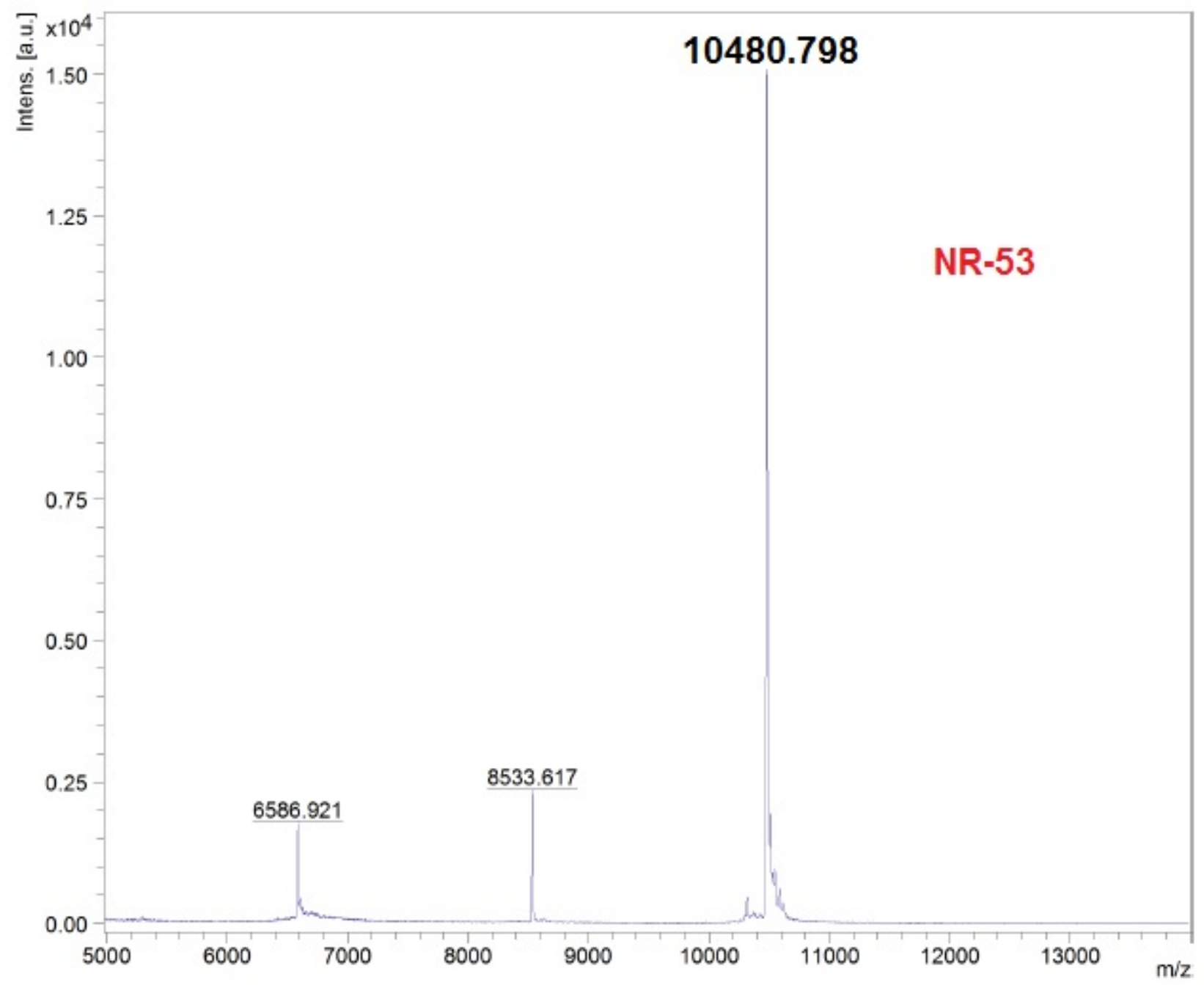

Figure S26. MALDI-TOF mass spectrum of NR-53. 
Table S4. Crystal data and structure refinement for NR-13.

\begin{tabular}{|c|c|}
\hline Empirical formula & $\mathrm{C}_{166} \mathrm{H}_{204} \mathrm{~N}_{10} \mathrm{O}_{4} \mathrm{~S}_{2} \mathrm{Si}_{4}$ \\
\hline Formula weight & 2579.86 \\
\hline Temperature/K & $150.00(10)$ \\
\hline Crystal system & triclinic \\
\hline Space group & $\mathrm{P}-1$ \\
\hline $\mathbf{a}(\AA)$ & $14.0797(4)$ \\
\hline b $(\AA)$ & $16.4437(7)$ \\
\hline c $(\AA)$ & $18.2596(11)$ \\
\hline$\alpha\left({ }^{\circ}\right)$ & $68.410(5)$ \\
\hline$\beta\left(\left(^{\circ}\right)\right.$ & $80.070(4)$ \\
\hline$\gamma\left({ }^{\circ}\right)$ & $75.458(3)$ \\
\hline Volume $\left(\AA^{3}\right)$ & $3789.9(3)$ \\
\hline $\mathbf{Z}$ & 1 \\
\hline d (calculated) $\left(\mathrm{g} / \mathrm{cm}^{3}\right)$ & 1.130 \\
\hline$\mu\left(\mathrm{mm}^{-1}\right)$ & 1.049 \\
\hline F (000) & 1390.0 \\
\hline Crystal size $\left(\mathrm{mm}^{3}\right)$ & $0.486 \times 0.219 \times 0.118$ \\
\hline Radiation & $\operatorname{CuK} \alpha(\lambda=1.54184)$ \\
\hline $2 \Theta$ range for data collection $\left({ }^{\circ}\right)$ & 7.846 to 137.996 \\
\hline $\begin{array}{l}\mathbf{h} \\
\mathbf{k} \\
\mathbf{l}\end{array}$ & $\begin{array}{l}-17 \leq \mathrm{h} \leq 17 \\
-19 \leq \mathrm{k} \leq 18 \\
-22 \leq 1 \leq 19\end{array}$ \\
\hline Reflections collected & 24989 \\
\hline Independent reflections & $13908[$ Rint $=0.0573$, Rsigma $=0.1009]$ \\
\hline Data/restraints/parameters & $13908 / 296 / 1017$ \\
\hline Goodness-of-fit on $\mathbf{F}^{2}$ & 1.022 \\
\hline Final $R$ indexes $[I>=2 \sigma(I)]$ & $\mathrm{R} 1=0.1066, \mathrm{wR} 2=0.2744$ \\
\hline Final $\mathbf{R}$ indexes [all data] & $\mathrm{R} 1=0.1455, \mathrm{wR} 2=0.3098$ \\
\hline Largest diff. peak/hole / e $\AA^{-3}$ & $1.50 /-0.90$ \\
\hline
\end{tabular}




\section{COMPUTER MODELLING}

A comparison of the geometrical and electronic properties of NR-13 against simplified NR13-H molecules where the solubilizing functional groups were substituted by $\mathrm{H}$ atoms was initially performed. For this, frontier orbitals computed with the B3LYP Hamiltonian with the 6-31G(d,p) basis set in chloroform for geometries optimized in vacuum and in chloroform and compared with NR-13 and NR-13-H were found to be very similar (Table S5).

Table S5. Frontier orbitals computed with the B3LYP Hamiltonian with the $6-31 \mathrm{G}(\mathrm{d}, \mathrm{p})$ basis set in chloroform for geometries optimized in vacuum and in chloroform with the same functional and basis set for NR-13 and NR-13-H. All values in eV.

\begin{tabular}{|c|c|c|c|c|c|c|c|c|c|c|c|}
\hline & \multicolumn{11}{|c|}{ B3LYP-6-31G(d,p)-Chloroform/B3LYP-6-31G(d,p) } \\
\hline & & & & & LUMO & HOMO & & & & & HOMO-LUMO gap \\
\hline NR-13 & -1.78 & -2.19 & -2.98 & -3.42 & -3.43 & -5.5 & -5.57 & -5.57 & -5.86 & -5.98 & 2.07 \\
\hline NR-13-H & -1.86 & -2.27 & -3.03 & -3.52 & -3.52 & -5.6 & -5.79 & -5.8 & -5.96 & -6.11 & 2.08 \\
\hline NR-13-H & -1.87 & -2.27 & -3.04 & -3.52 & -3.52 & -5.61 & -5.79 & -5.79 & -5.97 & -6.11 & 2.09 \\
\hline
\end{tabular}

Also, the first transition with a TD-B3LYP Hamiltonian was compared and found to be very similar for NR13 and NR-13-H (Table S6).

Table S6. TD-DFT $1^{\text {st }}$ excitation comparison for NR-13-H and NR-13.

\begin{tabular}{|l|l|l|l|l|l|l|}
\hline \multicolumn{3}{|l|}{ B3LYP-6-31G(d,p)-Chloroform/B3LYP-6-31G(d,p) } & \multicolumn{2}{l|}{ Experimental } \\
\hline & First Trans. / eV & Osc. Strenght & & First Trans. / eV & Osc. Strenght & Optical Gap / eV \\
\hline NR-13-H & 1.79 & 0.53 & NR-13 & 1.78 & 0.58 & 2 \\
\hline
\end{tabular}

Based on these results, NR-13-H, NR-33-H and NR-53-H, where chosen and computed for increased computational efficiency. To calculate the 3D structure of the NRs, semiempirical quantum mechanics were used to explore different conformers of the simplified NR-H molecules with GFN-xTB Hamiltonians which allow computing efficiently systems with thousands of atoms. ${ }^{9}$ To predict the most stable 3D structure of the different NRs, a simulated annealing run with the GFN0 method was first performed followed by ranking by, the more accurate, GFN2 method..$^{10}$ In addition, a global conformation search based on metadynamics with the CREST methodology and the GFN0 Hamiltonian ${ }^{11}$ was performed for NR-13-H. This produced four different conformers which were reoptimized with DFT at the B3LYP-6-31G(d,p) level. TD-DFT calculations were performed on the lowest energy minima found with the B3LYP-6-311+G(d,p)-Chloroform/B3LYP-6$31 \mathrm{G}(\mathrm{d}, \mathrm{p})$ Hamiltonian.

NICS(0) and ACID plots were computed with B3LYP-6-31G(d,p) for NR-13-H, NR-33-H, NR-53-H after a benchmark calculation with B3LYP-6-311+G(2d,p) for NR-13-H which produced a comparable trend. The NICS and the BLA (Bond Length Alternation) patterns were graphically analyzed with the help of the opensource software Jmol. ${ }^{12}$ All the DFT calculations were performed with the program Gaussian09. ${ }^{13}$ 


\section{REFERENCES}

1. Cortizo-Lacalle, D.; Mora-Fuentes, J. P.; Strutyński, K.; Saeki, A.; Melle-Franco, M.; Mateo-Alonso, A., Monodisperse N-Doped Graphene Nanoribbons Reaching 7.7 Nanometers in Length. Angew. Chem. Int. Ed. 2018, 57 (3), 703-708.

2. Holman, M. W.; Liu, R.; Adams, D. M., Single-Molecule Spectroscopy of Interfacial Electron Transfer. J. Am. Chem. Soc. 2003, 125 (41), 12649-12654.

3. Magde, D.; Brannon, J. H.; Cremers, T. L.; Olmsted, J., Absolute luminescence yield of cresyl violet. A standard for the red. J. Phys. Chem. 1979, 83 (6), 696-699.

4. Wagner, C.; Hübner, O.; Kaifer, E.; Himmel, H.-J., Probing the Proton-Coupled Electron-Transfer (PCET) Reactivity of a Cross-Conjugated Cruciform Chromophore by Redox-State-Dependent Fluorescence. Chem. Eur. J. 2019, 25 (15), 3781-3785.

5. Dubey, R. K.; Efimov, A.; Lemmetyinen, H., 1,7- And 1,6-Regioisomers of Diphenoxy and Dipyrrolidinyl Substituted Perylene Diimides: Synthesis, Separation, Characterization, and Comparison of Electrochemical and Optical Properties. Chem. Mater. 2011, 23 (3), 778-788.

6. Würthner, F.; Stepanenko, V.; Chen, Z.; Saha-Möller, C. R.; Kocher, N.; Stalke, D., Preparation and Characterization of Regioisomerically Pure 1,7-Disubstituted Perylene Bisimide Dyes. J. Org. Chem. 2004, 69 (23), 7933-7939.

7. Ji, L.; Krummenacher, I.; Friedrich, A.; Lorbach, A.; Haehnel, M.; Edkins, K.; Braunschweig, H.; Marder, T. B., Synthesis, Photophysical, and Electrochemical Properties of Pyrenes Substituted with Donors or Acceptors at the 4- or 4,9-Positions. J. Org. Chem. 2018, 83 (7), 3599-3606.

8. $\quad$ Liu, Z.; Wang, Y.; Chen, Y.; Liu, J.; Fang, Q.; Kleeberg, C.; Marder, T. B., Ir-Catalyzed Direct Borylation at the 4-Position of Pyrene. J. Org. Chem. 2012, 77 (16), 7124-7128.

9. Grimme, S.; Bannwarth, C.; Shushkov, P., A Robust and Accurate Tight-Binding Quantum Chemical Method for Structures, Vibrational Frequencies, and Noncovalent Interactions of Large Molecular Systems Parametrized for All spd-Block Elements $(\mathrm{Z}=1-86)$. J. Chem. Theory Comput. 2017, 13 (5), 1989-2009.

10. Bannwarth, C.; Ehlert, S.; Grimme, S., GFN2-xTB-An Accurate and Broadly Parametrized SelfConsistent Tight-Binding Quantum Chemical Method with Multipole Electrostatics and Density-Dependent Dispersion Contributions. J. Chem. Theory Comput. 2019, 15 (3), 1652-1671.

11. Pracht, P.; Bohle, F.; Grimme, S., Automated exploration of the low-energy chemical space with fast quantum chemical methods. Phys. Chem. Chem. Phys. 2020, 22 (14), 7169-7192.

12. Jmol: an open-source Java viewer for chemical structures in 3D. http://www.jmol.org/.

13. Gaussian 09, Revision D.01, M. J. Frisch, G. W. Trucks, H. B. Schlegel, G. E. Scuseria, M. A. Robb, J. R. Cheeseman, G. Scalmani, V. Barone, G. A. Petersson, H. Nakatsuji, X. Li, M. Caricato, A. Marenich, J. Bloino, B. G. Janesko, R. Gomperts, B. Mennucci, H. P. Hratchian, J. V. Ortiz, A. F. Izmaylov, J. L. Sonnenberg, D. Williams-Young, F. Ding, F. Lipparini, F. Egidi, J. Goings, B. Peng, A. Petrone, T. Henderson, D. Ranasinghe, V. G. Zakrzewski, J. Gao, N. Rega, G. Zheng, W. Liang, M. Hada, M. Ehara, K. Toyota, R. Fukuda, J. Hasegawa, M. Ishida, T. Nakajima, Y. Honda, O. Kitao, H. Nakai, T. Vreven, K. Throssell, J. A. Montgomery, Jr., J. E. Peralta, F. Ogliaro, M. Bearpark, J. J. Heyd, E. Brothers, K. N. Kudin, V. N. Staroverov, T. Keith, R. Kobayashi, J. Normand, K. Raghavachari, A. Rendell, J. C. Burant, S. S. Iyengar, J. Tomasi, M. Cossi, J. M. Millam, M. Klene, C. Adamo, R. Cammi, J. W. Ochterski, R. L. Martin, K. Morokuma, O. Farkas, J. B. Foresman, and D. J. Fox, Gaussian, Inc., Wallingford CT, 2016. 